\title{
ADMINISTRASI DAN SUPERVISI PENDIDIKAN
}

(Berbasis Standar Nasional Pendidikan)

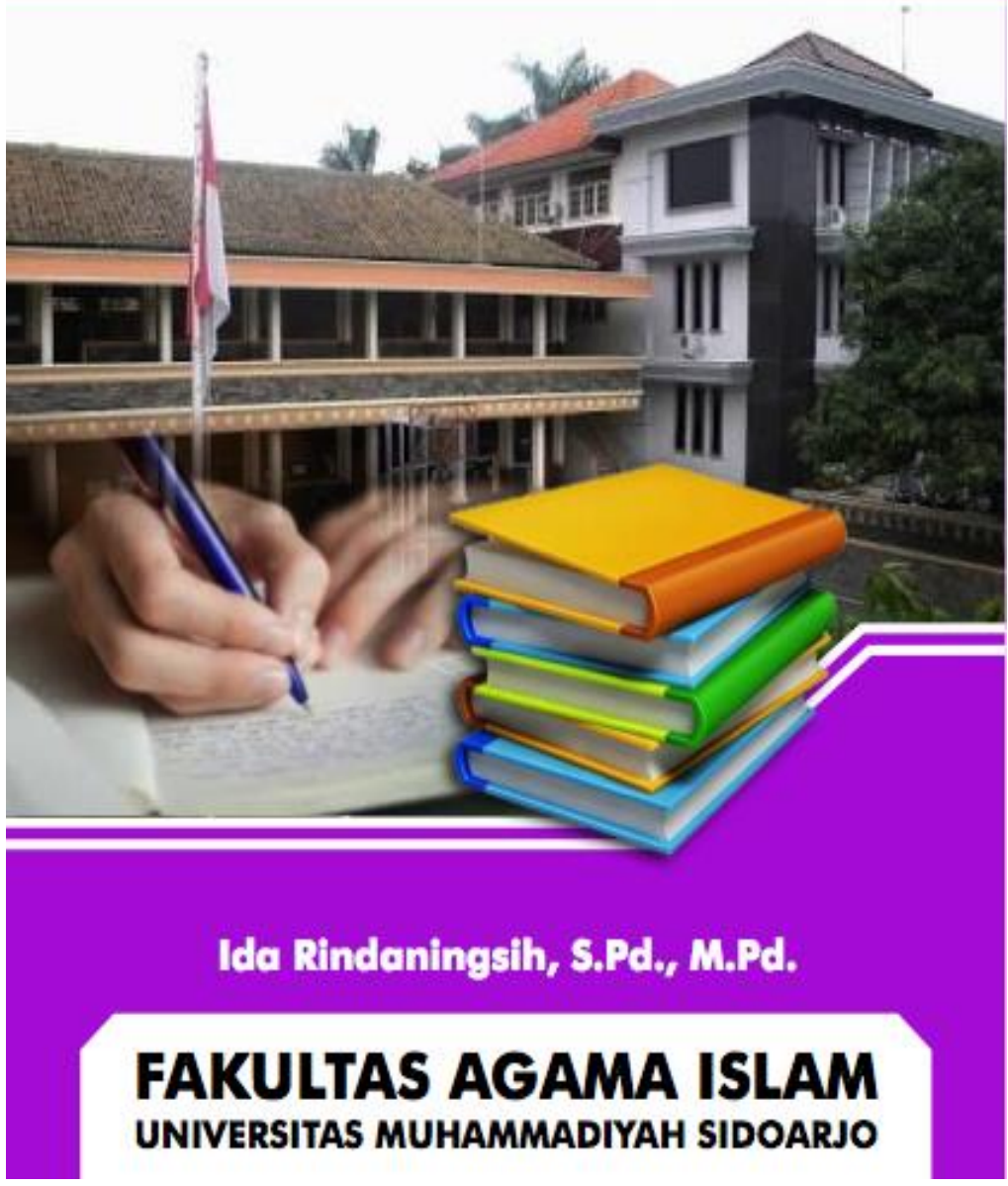




\section{BUKU AJAR \\ ADMINISTRASI DAN SUPERVISI PENDIDIKAN}

Penulis

Ida Rindaningsih, S.Pd., M.Pd.

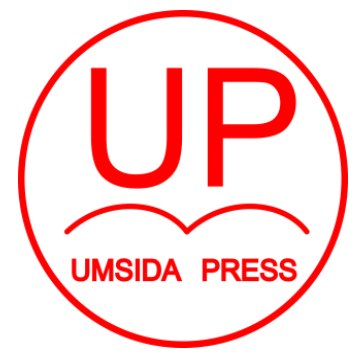

Diterbitkan oleh

\section{UMSIDA PRESS}

Jl. Mojopahit 666 B Sidoarjo

ISBN: 978-602-5914-17-1

Copyright@2018.

\section{Authors}

All rights reserved 


\section{BUKU AJAR}

\section{ADMINISTRASI DAN SUPERVISI PENDIDIKAN}

\section{Penulis :}

Ida Rindaningsih, S.Pd., M.Pd.

\section{ISBN :}

978-602-5914-17-1

\section{Editor :}

Septi Budi Sartika, M.Pd

M. Tanzil Multazam , S.H., M.Kn.

\section{Copy Editor :}

Fika Megawati, S.Pd., M.Pd.

\section{Design Sampul dan Tata Letak :}

Mochamad Nashrullah, S.Pd

\section{Penerbit :}

UMSIDA Press

\section{Redaksi :}

Universitas Muhammadiyah Sidoarjo

Jl. Mojopahit No 666B

Sidoarjo, Jawa TImur

Cetakan pertama, Agustus 2018

(C) Hak cipta dilindungi undang-undang

Dilarang memperbanyak karya tulis ini dengan suatu apapun tanpa ijin tertulis dari penerbit. 


\section{IDENTITAS BUKU}

Buku Administrasi dan Supervisi Pendidikan ini merupakan bekal awal bagi calon guru sekaligus tuntuan bagi guru maupun kepala sekolah. Buku ini memberikan pemahaman administrasi di sekolah disertai supervise Pendidikan. Serinfkali ketika menjadi guru atau kepala sekolah terjadi ketidakpahaman pentingnya tata kelola kelembagaan dalam admnistrasi dan supervise Pendidikan. Dan terjadi kebingungan saat akreditasi sekolah.

Untuk itulah buku ini berisikan tentang konsep administrasi Pendidikan, komponen dalam admistrasi Pendidikan, peran kepala sekolah dalam administrasi dan supervise Pendidikan. Semua isi dari buku ini disesuaikan dengan Standar Nasional Pendidikan (SNP). Dengan demikian buku ini diharapkan dapat meningkatkan pemahaman sekaligus implemetasinya di sekolah sehingga sekolah dapat meningkatkan mutu pendidikan 


\section{KATA PENGANTAR}

Syukur Alhamdulillah atas segala limpahan rahmat Allah SWT penulis mampu menyelesaikan buku Administrasi dan Supervisi Pendidikan berbasis Standar Nasional Pendidikan.

Meningkatnya kompetisi sekolah menuju lembaga yang bermutu tentunya tidak lepas dari peringkat akreditasi sekolah tersebut. Dalam hal ini diperlukan upaya sekolah dalam mewujudkan administrasi sekolah yang akuntabel dan supervisi pendidikan yang berkualitas. Buku ini memuat 6 BAB yang terdiri atas pengertian dan komponen Administrasi, Supervisi, dengan teknik dan modelmodel supervisi serta implementasi administrasi pendidikan di sekolah berdasarkan SNP.

Ucapan terima kasih pada UMSIDA yang telah memotivasi dan memfasilitasi penulisan hingga penerbitan buku ini. Untuk itu semoga karya ini bermanfaat bagi pembaca sekaligus menjadi wacana penataan administrasi dan supervisi di sekolah 


\section{DAFTAR ISI}

Halaman Judul

Identitas Buku ii

Kata Pengantar iii

Daftar Isi iv

BAB I Kajian Administrasi Pendidikan 1

A. Konsep Administrasi Pendidikan ...................................... 1

B. Administrasi Pendidikan 8

C. Tujuan dan Fungsi Administrasi Pendidikan ...................... 10

D. Ruang Lingkup Administrasi Pendidikan ........................... 11

BAB II Komponen Administrasi Pendidikan ......................... 15

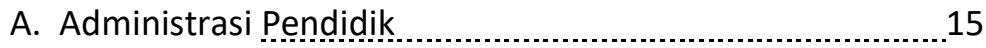

B. Administrasi Peserta Didik ........................................... 19

C. Administrasi Kurikulum ................................................ 35

D. Administrasi Sarana dan Prasarana Pendidikan _................ 41

E. Administrasi Keuangan ...............................................49

BAB III Peranan Kepala Sekolah.Madrasah dalam Administrasi Pendidikan ............................................................... 53

A. Syarat Kepala Sekolah................................................. 54

B. Kepemimpinan Kepala Sekolah .................................... 55

C. Tugas dan Tanggung Jawab Kepala Sekolah.......................58

D. Kompetensi Kepala Sekolah ............................................ 61

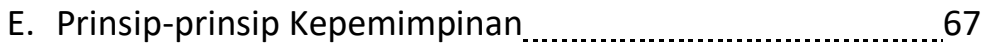

F. Visionary leadership kepala sekolah _......................... 72

BAB IV Supervisi Pendidikan ............................................. 76

A. Supervisi Pendidikan ........................................................ 76

B. Tujuan Supervisi Pendidikan ...................................... 78

C. Prinsip Supervisi Pendidikan............................................ 79

D. Fungsi Supervisi Pendidikan ........................................... 81

E. Objek Supervisi Pendidikan ......................................... 82 
BAB V Model, Pendekatan dan Teknik Supervisi

86

A. Model Supervisi Pendidikan ...........................................86

B. Pendekatan Supervisi .......................................... 88

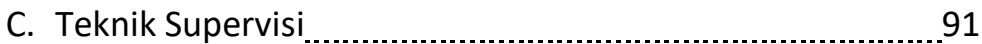

BAB VI Administrasi Pendidikan dalam SNP ........................ 98

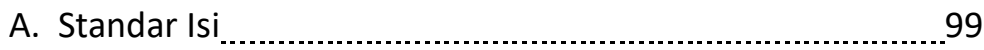

B. Standar Proses ...................................................... 99

C. Standar Kompetensi Lulusan ............................................ 100

D. Standar Pendidik dan Tenaga Kependidikan .......................101

E. Standar Sarana dan Prasarana $\ldots 102$

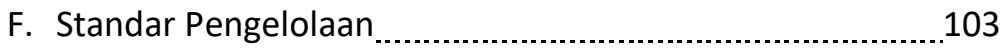

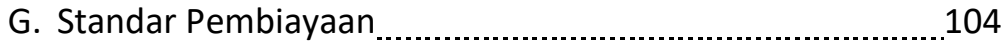

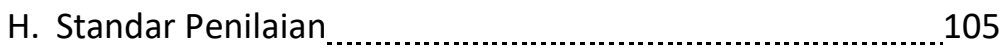

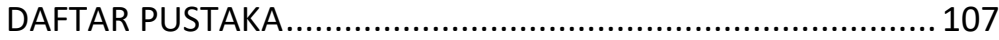




\section{BAB I \\ Kajian Administrasi Pendidikan}

\section{A. Konsep Administrasi}

Administrasi merupakan suatu kegiatan yang melibatkan sumber daya manusia. Jika dikaitkan dengan pendidikan, maka administrasi pendidikan merupakan kegiatan yang ditujukan untuk mengoptimalkan (efektif dan efisien) pencapaian tujuan pendidikan melalui penataan berbagai sumber daya, manusia, kurikulum dan fasilitas. Administrasi Secara sederhana administrasi berasal dari kata latin "ad" dan "ministro". Ad mempunyai arti "kepada" dan ministro berarti "melayani". Secara bebas dapat diartikan bahwa administrasi itu merupakan pelayanan atau pengabdian terhadap subjek tertentu. Sedangkan dalam bahasa Inggris. Kata " $a d$ " mempunyai arti yang sama dengan kata "to", yang berarti "ke" atau "kepada". Dan ministrare sama artinya dengan kata to serve atau to conduct yang berarti "melayani", "membantu", atau "mengarahkan". Dalam bahasa Inggris to administer berarti pula "mengatur", "memelihara" (to look after), dan "mengarahkan"

Administrasi berasal dari Bahasa Latin Administrare yang memiliki arti membantu atau melayani. Dalam bahasa Inggris perkataan administrasi berasal dari kata administration, yang artinya melayani, mengendalikan, atau mengelola suatu organisasi dalam mencapai tujuannya secara intensif.

Ditinjau dari katanya, administrasi mempunyai arti sempit dan arti luas. Dalam arti sempit diartikan sebagai kegiatan pencatatan data, surat-surat informasi secara tertulis serta penyimpanan dokumen sehingga dapat dipergunakan kembali bila diperlukan. Dalam hal ini kegiatan administrasi meliputi pekerjaan tata usaha. Dalam arti luas, administrasi menyangkut kegiatan manajemen/pengelolaan 
terhadap keseluruhan komponen organisasi untuk mewujudkan tujuan/program organisasi. Dengan demikian dapat dikatakan bahwa pekerjaan administrasi merupakan pekerjaan operatif dan manajemen.

Berdasarkan definisi administrasi sebagaimana dikemukakan di atas administrasi mengandung unsur sebagai berikut:

1. Adanya sekelompok manusia, (sedikitnya 2 orang)

2. Adanya tujuan yang hendak dicapai

3. Adanya tugas/fungsi yang harus dilaksanakan (kegiatan kerjasama)

4. Adanya peralatan dan perlengkapan yang diperlukan.

Namun sebagian ahli yang lain berpendapat bahwa administrasi berbeda dengan manajemen, di mana administrasi diposisikan dalam lingkup yang lebih luas dan manajemen merupakan bagian inti dari administrasi. Administrasi bersifat konseptual yang menentukan tujuan dan kebijakan umum secara menyeluruh sedangkan manajemen yang lebih bersifat operasional sebagai subkonsep yang tugasnya melaksanakan semua kegiatan untuk mencapai tujuan dan kebijaksanaan yang sudah tertentu pada tingkat administrasi. Administrasi penekanannya terletak pada pembuatan kebijakan menyeluruh, perencanaan, pembuatan program, penyiapan anggaran (budget), pendekatan sistem, dan pengawasan. Dari pemahaman tersebut dapat disimpulkan bahwa dengan manajemen, administrasi akan mencapai tujuannya.

Selanjutnya para ahli juga mendefinisikan tentang administrasi, diantaranya adalah sebagai berikut:

a. Menurut Henri Fayol

Administrasi adalah fungsi dalam organisasi niaga unsurunsurnya adalah perencanaan, pengorganisasian, pemberi 
perintah, pengkoordinasian, dan pengawasan. Administrasi merupakan proses yang menyeluruh dan terdiri dari berbagai kegiatan yang berhubungan dan bersambungan.

b. Menurut Orway Tead

Administrasi adalah usaha luas yang mecakup segala bidang untuk memimpin, mengusahakan, mengatur, kegiatan kerjasama manusia yang ditunjukan pada tujuan-tujuan dan maksud-maksud tertentu.

c. Menurut Ulbert

Administrasi dalam arti sempit di artikan sebagai penyusunan dan pencatatan data dan informasi secara berurut baik dari dalam maupun dari luar dengan tujuan menyediakan keterangan serta memudahkan untuk mendapatkan kembali baik sebagian maupun menyeluruh. Definisi administrasi secara sempit ini lebih dikenal dengan istilah Tata Usaha.

d. Menurut WH Evans

Administrasi ialah fungsi yang melibatkan manajemen dan pengarahan semua bagian operasi perusahaan tentang pengolahan materi keterangan, komunikasi, dan ingatan organisasi.

e. Menurut Arthur Grager

Administrasi merupakan fungsi tata penyediaan terhadap komunikasi dan pelayanan surat suatu organisasi.

f. Menurut William Leffingwell dan Edwin Robinson

Administrasi merupakan cabang ilmu manajemen yang terlibat dengan pelaksanaan pekerjaan perkantoran secara efisien, kapan, dan dimana pekerjaan itu harus dilaksanakan.

g. Menurut George Terry

Administrasi ialah perencanaan, pengendalian, dan pengorganisasian pekerjaan perkantoran, serta penggerakan mereka yang melakukannya agar mencapai tujuan yang telah distabilkan. 
Administrasi sebagai proses rangkaian kegiatan memiliki unsur sebagai berikut:

1. Organisasi

Unsur administrasi yang pertama adalah organisasi. Jika sekelompok individu menghadapi pekerjaan yang sudah tidak mampu lagi untuk ditangani oleh satu orang, muncullah organisasi. Organisasi dalam pengertian dinamisnya merupakan sesuatu yang berhubungan dengan bentuk dan pola dalam rangka kerja sama dengan membagi habis semua tugas yang ada secara tepat dan proporsional agar tujuan bersama yang telah ditetapkan dapat tercapai. Sedangkan organisasi dalam pengertian statisnya merupakan bentuk sekumpulan orang yang memiliki tujuan yang sama yang ingin dicapainya. Pekerjaan yang telah terbagi-bagi kepada banyak personil itu lalu digabungkan kembali dengan membentuk sinergi dan harmonisasi kegiatan/ pekerjaan dalam sebuah organisasi.

2. Manajemen

Unsur administrasi yang kedua adalah manajemen. Menurut Stephen P. Robbins dan Mary Coulter (1999: 8), manajemen adalah proses mengkoordinasi dan mengintegrasikan kegiatan-kegiatan kerja agar diselesaikan secara efisien dan efektif dengan dan melalui orang lain.

3. Komunikasi

Unsur administrasi yang ketiga adalah komunikasi yang berhubungan dengan persoalan menyampaikan pesan dari satu pihak kepada pihak yang lain dalam rangka kerja sama dalam suatu organisasi untuk mencapai tujuan bersama.

4. Kepegawaian

Unsur administrasi yang keempat adalah kepegawaian yang berhubungan dengan persoalan sumber daya manusia, mulai dari penerimaan, pengembangan, hingga pemberhentiannya. 


\section{Keuangan}

Unsur administrasi yang kelima adalah keuangan yang berhubungan dengan pembiayaan dalam suatu usaha kerja sama. 6. Perbekalan/Sarana/Prasarana

Unsur administrasi yang keenam adalah perbekalan/sarana/prasarana yang berhubungan dengan persoalan penelitian, pengadaan, pemanfaatan, penyimpanan, dan perawatan gedung, peralatan, barang-barang, serta perlengkapan, hingga penghapusan perlengkapan dari proses administrasi.

7. Ketatausahaan

Unsur administrasi yang ketujuh adalah ketatausahaan yang berhubungan dengan persoalan menyiapkan, membuat, mengirim, mencatat bahan- bahan keterangan atau proses yang dimulai dari mengumpulkan, mencatat, memproses (konsep surat/keputusan/korespondensi), memperbanyak, mengirim (ekspedisi) dan menyimpan (pengarsipan) semua bahan-bahan yang berkaitan dengan informasi yang dibutuhkan dalam suatu organisasi untuk dapat mencapai tujuannya. Informasi yang masih mentah akan diolah sehingga dapat dipakai oleh setiap bagian yang membutuhkan atau berkaitan dengannya.

8. Hubungan Masyarakat

Unsur administrasi yang kedelapan adalah hubungan masyarakat yang berhubungan dengan penjalinan hubungan baik atau kerja sama dalam suatu organisasi dengan instansi/unit usaha lain yang ada di lingkungannya.

Prajudi Atmosudirdjo (1979) mengemukakan bahwa kehidupan manusia mengalami perkembangan dari yang semula manusia primitif, nomaden, beradat, hingga menjadi manusia modern. Kemajuan yang dicapai manusia itu meliputi cara berpikir dan cara hidup bermasyarakatnya. Manusia modern dipandang atau diukur dari kemampuan serta cara berpikir dan pranata/sistem 
kehidupannya secara sederhana dapat dikelompokkan sebagai berikut:

1. Manusia kerja (homo faber), adalah manusia yang sudah mengetahui banyak tentang alam sekitarnya dengan cara mempelajari alam, unsur- unsur, dan hukum-hukumnya sehingga masyarakat tersebut dapat menaklukkan alam dan memanfaatkannya bagi kepentingan masyarakatnya.

2. Manusia birokrasi, adalah manusia yang suka pekerjaan kertas (paper work) yang telah sadar akan pentingnya surat-menyurat untuk mengatur dan menguasai pekerjaan. Manusia birokrasi suka kepada pekerjaan ajeg dan teratur, pekerjaan tertentu yang berdasarkan spesialisasi dan pembagian kerja, bekerja teratur berdasarkan perintah, bekerja secara lugas (impersonal), tidak melayani kehendak atau kesewenangan orang per orang (pribadi).

3. Manusia organisasi, adalah lanjutan dari manusia birokrasi. la adalah individu yang mampu mengendalikan sekelompok orang untuk bekerja sama dalam sebuah tim, bersikap tegas, disiplin, mematuhi segala sesuatu di dalam peraturan yang berlaku/konstitusi, anggaran dasar, dan moral organisasi. la bekerja secara organisatoris. Ia telah biasa dengan adanya pelimpahan kewenangan (delegation of authortity).

4. Manusia manajemen, adalah manusia rasional. la adalah individu yang mampu mengendalikan dan mengembangkan operasi kerja melalui kemampuan perencanaan (planning), penggerakkan (actuating), dan fungsi manajemen lainnya. Manusia manajemen kuat dalam pengendalian dan pengembangan sistem, operasi, dan organisasi kerja yang terdiri atas berbagai macam kesatuan organisasi dan sistem kerja sekaligus.

5. Manusia administrasi, adalah manusia yang mampu mengendalikan kinerjanya secara efektif dan efisien. Kekuatannya terletak terutama pada pembuatan kebijakan, tindakan yang 
menyeluruh dan terencana, pembuatan program, penyiapan anggaran, pendekatan sistem dan pengawasan.

Dari uraiannya di atas, maka Prajudi Atmosudirdjo (1979) menyimpulkan bahwa untuk menjadi manusia modern diawali dengan menjadi manusia kerja, selanjutnya menjadi manusia manajemen, dan setelah itu baru menjadi manusia administrasi yang menjadi dasarnya adalah manusia birokrasi. la mengemukakan bahwa administrasi dapat ditinjau dari tiga sudut, yaitu:

1. Sudut Proses. Ditinjau dari sudut proses, administrasi merupakan segala kegiatan yang dilakukan untuk mencapai tujuan yang diawali dengan proses pemikiran (konseptual), pelaksanaan, hingga tercapainya tujuan yang telah ditetapkan itu.

2. Sudut Fungsi. Ditinjau dari sudut fungsi, administrasi terdiri dari berbagai fungsi atau tugas dalam segala kegiatan yang dilakukan untuk mencapai tujuan tersebut, contoh seperti fungsi perencanaan, pergerakan dan pengawasan / pengendalian.

3. Sudut Kelembagaan. Ditinjau dari sudut kelembagaan, administrasi merupakan kelembagaan secara keseluruhan dengan berbagai kegiatan di dalamnya untuk mencapai tujuan yang mana kegiatan tersebut bersifat holistik dari tingkat atas hingga tingkat bawah. Dalam berbagai kegiatan ini melibatkan empat jenis personil, yaitu:

a. Personil yang menjadi pemikir dan menetapkan tujuan yang disebut sebagai administrator.

b. Personil yang memimpin dan mengendalikan usaha agar tujuan organisasi dapat tercapai yang disebut sebagai manajer.

c. Personil yang membantu manajer dengan memberikan pertimbangan teknis atau sumbangan pemikiran yang 
diperlukan oleh pimpinan untuk mengambil suatu keputusan apa dan bagaimana suatu usaha akan dibuat dan dijalankan. Personil yang tugasnya seperti ini disebut sebagai staf ahli.

d. Personil yang bertugas melaksanakan pekerjaan secara langsung di bidang-bidang yang telah ditentukan dalam unit kerjanya yang disebut sebagai staf atau pegawai.

\section{B. Administrasi Pendidikan}

Pendidikan merupakan sistem proses perubahan menuju pencerdasan, pendewasaan, dan pematangan diri. Memperoleh pendidikan yang layak adalah kewajiban sekaligus hak asasi setiap orang untuk menjadi matang, terampil, dan cerdas sebagai bekal untuk menjalani kehidupannya.

Pendidikan berlangsung dalam segala jenis, bentuk, dan jenjangnya yang mendorong perkembangan potensi setiap individu dalam sebuah masyarakat bagi mewujudkan masyarakat yang maju dan beradab

Dari pemahaman tentang administrasi dan pendidikan di atas administrasi pendidikan dapat diartikan sebagai keseluruhan proses bekerja sama dengan memanfaatkan semua sumber daya yang tersedia dan dibutuhkan untuk mencapai tujuan pendidikan yang telah ditetapkan secara efektif dan efisien. Menurut Satori (1980), administrasi pendidikan merupakan keseluruhan proses kerjasama dengan memanfaatkan semua sumber personil dan materil yang tersedia dan sesuai untuk mencapai tujuan pendidikan yang telah ditetapkan secara efektif dan efisien. Castetter (1996) mengungkapkan bahwa, "educational administration is a social process that take place within the context of social system".

Administrasi pendidikan pada dasarnya merupakan administrasi dalam mengelola, mengatur dan mengalokasikan sumber daya 
yang terdapat dalam dunia pendidikan. Fungsi administrasi pendidikan merupakan alat untuk menyatukan dan menyelaraskan peranan seluruh sumberdaya yang dimiliki guna tercapainya tujuan pendidikan dalam suatu konteks sosial tertentu, ini berarti bahwa bidang-bidang yang dikelola mempunyai kekhususan yang berbeda dari manajemen dalam bidang lain.

Administrasi pendidikan pada dasarnya merupakan administrasi dalam mengelola, mengatur dan mengalokasikan sumber daya yang terdapat dalam dunia pendidikan. Fungsi administrasi pendidikan merupakan alat untuk menyatukan dan menyelaraskan peranan seluruh sumberdaya yang dimiliki guna tercapainya tujuan pendidikan dalam suatu konteks sosial tertentu, ini berarti bahwa bidang-bidang yang dikelola mempunyai kekhususan yang berbeda dari manajemen dalam bidang lain.

Oteng Sutisna (1989) menyatakan bahwa administrasi pendidikan meliputi:

1. Latar belakang administrasi pendidikan (geografi, kependudukan, ekonomi, ideologi, kebudayaan, dan pembangunan);

\section{Bidang garapannya;}

Unsur-unsur pokok administrasi pendidikan, seperti tugas-tugas, proses, asas-asas, dan perilaku administrasi memberikan gambaran bahwa administrasi pendidikan mempunyai bidang dengan cakupan yang luas dan saling berkaitan, sehingga pemahaman tentangnya memerlukan wawasan yang luas serta antisipatif terhadap berbagai perubahan yang terjadi di masyarakat di samping pendalaman dari segi perkembangan teori administrasi.

Adminitrasi dilakukan melalui kerjasama berbagai orang, orientasi pelaksanaan administrasi pendidikan diarahkan untuk mencapai tujuan pendidikan, administrasi pendidikan memanfaatkan sumber daya pendidikan secara optimal, adminstrasi pendidikan dilaksanakan berdasarkan fungsi manajerial pendidikan. 


\section{Tujuan dan Fungsi Administrasi Pendidikan}

Tujuan pendidikan sebagai berikut: a). tujuan pendidikan merupakan jabaran dari tujuan pendidikan nasional. Oleh karena itu, pemahaman tentang hubungan keduanya perlu dilakukan. b), tujuan pendidikan merupakan titik berangkat administrasi pendidikan pada jenjang sekolah, dan c), tujuan pendidikan itu juga merupakan tolak ukur keberhasilan kegiatan administrasi pendidikan di jenjang pendidikan itu.Tujuan pendidikan itu menjadi filsafat hidup (pandangan hidup) suatu bangsa yang melakukan aktivitas pendidikan.

Sedangkan tujuan administrasi pendidikan adalah agar semua kegiatan yang mendukung tercapainya tujuan pendidikan. Kemudian menurut Sergiovani dan Carver adalah efektivitas produksi, efesien, kemampuan menyesuaikan diri, dan kepuasan kerja.

Secara umum tujuan administrasi pendidikan di Indonesia yang dilaksanakan di sekolah juga bersumber dari tujuan pendidikan Nasional yang digariskan dalam undang-undang no. 20 tahun 2003 tentang sistem pendidikan nasional pasal 3, "tujuan pendidikan nasional adalah mengembangkan potensi peserta didik agar menjadi manusia yang beriman dan bertakwa kepada Tuhan Yang Maha Esa, berakhlak mulia, sehat, berilmu, cakap, kreatif, mandiri, dan menjadi warga negara yang demokratis serta bertanggung jawab"

Kegiatan administrasi pendidikan melibatkan banyak pihak seperti kepala sekolah, para pembina, pengawas, serta pejabat departemen pendidikan. Keterlibatan tersebut meliputi fungsi dan tugas masing. Semua unsur yang terlibat berkontribusi terhadap peningkatan dan pencapaian tujuan pendidikan. Boleh dikatakan bahwa semua unsur tersebut adalah bagian dari administrator 
pendidikan. Keberhasilan kegiatan administrasi pendidikan dalam jangka panjang dapat dilihat dari sejauh mana tujuan pendidikan dapat diwujudkan. Untuk mencapai hasil yang maksimal tersebut dibutuhkan tenaga administrator pendidikan yang handal dan bertanggung jawab.Dalam kaitan ini administrasi pendidikan berfungsi untuk mengkordinasikan perilaku manusia dalam pendidikan untuk menata sumber daya yang ada dengan sebaikbaiknya sehingga tujuan pendidikan dapat tercapai secara produktif.

\section{Ruang Lingkup Administrasi Pendidikan}

Ruang lingkup administrasi pendidikan meliputi bidang sumber daya manusia, kurikulum, proses belajar mengajar, sarana/prasarana, dan dana yang diperlukan dalam upaya untuk mencapai tujuan pendidikan, baik bagi perorangan maupun kelembagaan. Dalam kegiatan administrasi pendidikan sangat diperlukan pengintegrasian dari berbagai sumber daya dan modal yang dibutuhkan bagi pencapaian tujuan pendidikan, seperti sumber daya manusia yang sangat menentukan bagi mutu proses pem- belajarannya dan sumber daya keuangan merupakan dana yang diperlukan untuk melaksanakan dan memperbaiki proses pendidikan, di samping modal sosial yang merupakan ikatan kepercayaan dan kebiasaan yang menggambarkan sekolah sebagai komunitas, dan modal politik yang meliputi dasar otoritas legal yang dimiliki untuk melakukan proses pembelajaran/ pendidikan.

Dr. Hadai Nawawi menyatakan, bahwa secara umum ruang lingkup administrasi pendidikan adalah sebagai berikut :

1. Manajemen administratif, yakni kegiatan-kegiatan yang bertujuan mengarahkan agar semua orang dalam organisasi atau kelompok kerjasama mengerjakan hal-hal yang tepat sesuai dengan tujuan yang hendak dicapai. 
2. Manajemen operatif, yakni kegiatan-kegiatan yang bertujuan mengarahkan dan membina agar dalam mengerjakan pekerjaan yang menjadi bahan tugas masing-masing setiap orang melaksanakan dengan tepat dan benar

Dalam hal ruang lingkup bidang kajian Ilmu Administrasi ini pokoknya adalah semua bentuk usaha bersama untuk mencapai tujuan pendidikan dengan merancang, mengadakan, dan memanfaatkan sumber-sumber (manusia, uang, peralatan, dan waktu).Tujuan pendidikan memberikan arah kegaitan serta kriteria keberhasilan kegiatan itu.

\begin{tabular}{|l|l|l|l|}
\hline Fungsi Garapan & SDM & SB & SFD \\
\hline Perencanaan & & & \\
\hline Pelaksanaan & & & \\
\hline Pengawasan & & & \\
\hline
\end{tabular}

Gambar di atas menunjukan suatu kombinasi antara fungsi manajemen dengan bidang garapan yakni sumber Daya manusia (SDM), Sumber Belajar (SB), dan Sumber Fasilitas dan Dana (SFD), sehingga tergambar apa yang sedang dikerjakan dalam konteks manajemen pendidikan dalam upaya untuk mencapai Tujuan Pendidikan secara Produktif (TPP) baik untuk perorangan maupun kelembagaan.

\section{E. Pengertian Standar Nasional Pendidikan}

Standar Nasional Pendidikan adalah kriteria minimal tentang sistem pendidikan di seluruh wilayah hukum Negara Kesatuan Republik Indonesia. Peraturan Pemerintah Nomor 19 Tahun 2005 tentang Standar Nasional Pendidikan perlu diselaraskan dengan dinamika perkembangan masyarakat, lokal, nasional, dan global guna mewujudkan fungsi dan tujuan pendidikan nasional.

Pasal 5 ayat (2) Undang-Undang Dasar Negara bahwa dalam rangka mencerdaskan kehidupan bangsa diperlukan komitmen nasional 
untuk meningkatkan mutu dan daya saing bangsa melalui pengaturan kembali Standar Kompetensi Lulusan, standar isi, standar proses, dan standar penilaian, serta pengaturan kembali kurikulum. Standar Nasional Pendidikan terdiri dari :

1. Standar Kompetensi Lulusan

2. Standar Isi

3. Standar Proses

4. Standar Pendidikan dan Tenaga Kependidikan

5. Standar Sarana dan Prasarana

6. Standar Pengelolaan

7. Standar Pembiayaan Pendidikan

8. Standar Penilaian Pendidikan

Fungsi dan Tujuan Standar :

1. Standar Nasional Pendidikan berfungsi sebagai dasar dalam perencanaan, pelaksanaan, dan pengawasan pendidikan dalam rangka mewujudkan pendidikan nasional yang bermutu

2. Standar Nasional Pendidikan bertujuan menjamin mutu pendidikan nasional dalam rangka mencerdaskan kehidupan bangsa dan membentuk watak serta peradaban bangsa yang bermartabat.

3. Standar Nasional Pendidikan disempurnakan secara terencana, terarah, dan berkelanjutan sesuai dengan tuntutan perubahan kehidupan lokal, nasional, dan global. 


\section{LATIHAN SOAL}

KERJAKAN SOAL DIBAWAH INI

1. Jelaskan pengertian Administrasi Pendidikan?

2. Sebutkan unsur-unsur dalam administrasi?

3. Jelaskan Fungsi Administrasi Pendidikan?

4. Jelaskan Ruang lingkup Administrasi Pendidikan?

5. Apa yang dimaksud SNP dan sebutkan terdiri apa saja dalam SNP? 


\section{BAB II \\ Komponen Administrasi Pendidikan}

\section{A. Administrasi Pendidik dan Tenaga Kependidikan}

Pendidik harus memiliki kualifikasi akademik dan kompetensi sebagai agen pembelajaran, sehat jasmani dan rohani, serta memiliki kemampuan untuk mewujudkan tujuan pendidikan nasional.

Kualifikasi akademik yang dimaksudkan di atas adalah tingkat pendidikan minimal yang harus dipenuhi oleh seorang pendidik yang dibuktikan dengan ijazah dan/atau sertifikat keahlian yang relevan sesuai ketentuan perundang-undangan yang berlaku.

Kompetensi sebagai agen pembelajaran pada jenjang pendidikan dasar dan menengah serta pendidikan anak usia dini meliputi:

* Kompetensi pedagogik;

* Kompetensi kepribadian;

* Kompetensi profesional; dan

* Kompetensi sosial.

Pendidik meliputi pendidik pada TK/RA, SD/MI, SMP/MTs, SMA/MA, SDLB/SMPLB/SMALB, SMK/MAK, satuan pendidikan Paket $A$, Paket $B$ dan Paket $C$, dan pendidik pada lembaga kursus dan pelatihan.

Tenaga kependidikan meliputi kepala sekolah/madrasah, pengawas satuan pendidikan, tenaga administrasi, tenaga perpustakaan, tenaga laboratorium, teknisi, pengelola kelompok belajar, pamong belajar, dan tenaga kebersihan.

Berikut ini, Peraturan Menteri Pendidikan Nasional Republik Indonesia yang berkaitan dengan Standar Pendidik dan Tenaga Kependidikan.

* Peraturan Menteri Pendidikan Nasional Republik Indonesia No 12 Tahun 2007 tentang Standar Pengawas Sekolah/Madrasah. 
* Peraturan Menteri Pendidikan Nasional Republik Indonesia № 13 Tahun 2007 tentang Standar Kepala Sekolah/Madrasah.

* Peraturan Menteri Pendidikan Nasional Republik Indonesia No 16 Tahun 2007 tentang Standar Kualifikasi Akademik dan Kompetensi Guru.

* Peraturan Menteri Pendidikan Nasional Republik Indonesia № 24 Tahun 2008 tentang Standar Tenaga Administrasi Sekolah.

* Peraturan Menteri Pendidikan Nasional Republik Indonesia № 25 Tahun 2008 tentang Standar Tenaga Perpustakaan Sekolah/Madrasah.

* Peraturan Menteri Pendidikan Nasional Republik Indonesia № 27 Tahun 2008 tentang Standar Kulifikasi Akademik dan Kompetensi Konselor.

* Peraturan Menteri Pendidikan Nasional Republik Indonesia № 40 Tahun 2009 tentang Standar Penguji pada kursus dan pelatihan.

* Peraturan Menteri Pendidikan Nasional Republik Indonesia № 41 Tahun 2009 tentang Standar kualifikasi pembimbing pada kursus dan pelatihan.

* Peraturan Menteri Pendidikan Nasional Republik Indonesia № 42 Tahun 2009 tentang Standar Pengelola Kursus dan Pelatihan.

* Peraturan Menteri Pendidikan Nasional Republik Indonesia № 43 Tahun 2009 Standar Tenaga administrasi pendidikan pada program Paket A, Paket B, dan Paket C.

* Peraturan Menteri Pendidikan Nasional Republik Indonesia Nomor 44 Tahun 2009 Standar Pengelola pendidikan pada Program Paket A, Paket B, dan Paket C.

Secara umum pendidik di Indonesia lebih dikenal dengan pengajar, adalah tenaga kependidikan yang berpartisipasi dalam menyelenggarakan pendidikan dengan tugas khusus sebagai profesi pendidik. Pendidik mempunyai sebutan lain sesuai 
kekhususannya yaitu: Guru, Dosen, Konselor, Pamong belajar, widyaiswara, tutor, instruktur, fasilitator. Sedangkan dalam UU No. 20 thn 2003 BAB XI Pendidik dan tenaga kependidikan pasal 39 mengatakan bahwa pendidik merupakan tenaga profesional yang bertugas merencanakan dan melaksanakan proses pembelajaran, menilai hasil pembelajaran, melakukan pembimbingan dan pelatihan, serta melakukan penelitian dan pengabdian kepada masyarakat, terutama bagi pendidik pada perguruan tinggi.

Pendidik merupakan: ${ }^{1)}$ tenaga profesional, ${ }^{2)}$ merencanakan pembelajaran. ${ }^{3)}$ melaksanakan pembelajaran. ${ }^{4}$ menilai hasil pembelajaran. ${ }^{5)}$ membimbing. ${ }^{6 /}$ melatih. ${ }^{7 /}$ meniliti. ${ }^{8 /}$ mengabdi kepada masyarakat.

Jadi, jika diatas dikatakan bahwa pendidik adalah guru. maka administrasi yang dimaksud disini adalah perangkat pembelajaran. Apa saja yang harus disiapkan oleh guru berkaitan perangkat atau administrasi pembelajaran yaitu sebagai berikut:

\begin{tabular}{|c|l|}
\hline Nomor & \multicolumn{1}{|c|}{ Jenis Perangkat Administrasi } \\
\hline 1. & Silabus \\
\hline 2. & Kalender Pendidikan \\
\hline 3. & Program Tahunan \\
\hline 4. & Program Semester \\
\hline 5. & Rencana Pelaksanaan Pembelajaran \\
\hline 6. & Rencana Pelaksanaan Harian \\
\hline 7. & Buku Pelaksanaan Harian \\
\hline 8. & Presensi Siswa \\
\hline 9. & Catatan Hambatan Belajar Siswa \\
\hline 10. & Daftar Buku Pegangan Guru \\
\hline & \\
\hline 11. & Analisis KKM \\
\hline
\end{tabular}




\begin{tabular}{|c|l|}
\hline 12. & Kisi-kisi Soal \\
\hline 13. & Soal-soal Ulangan \\
\hline 14. & Buku Informasi Penilaian \\
\hline 15. & Analisis Butir Soal \\
\hline 16. & Analisis Hasil Ulangan \\
\hline 17. & Program/Pelaksanaan Perbaikan \\
\hline 18. & Program/Pelaksanaan Pengayaan \\
\hline 19. & Daftar Pengembalian Hasil Ulangan \\
\hline 20. & Buku Ulangan Bergilir \\
\hline 21. & Daftar Nilai \\
\hline 22. & Laporan Penilaian Akhlak Mulia dan Kepribadian Siswa \\
\hline 23. & Buku Tugas Terstruktur \\
\hline 24. & Buku Tugas Mandiri \\
\hline & \\
\hline 1. & SK Pembagian Tugas \\
\hline 2. & Mengisi Buku Kemajuan Kelas \\
\hline 3. & Jadwal Mengajar \\
\hline
\end{tabular}

UU No. 20 thn 2003 BAB XI Pendidik dan tenaga kependidikan pasal 39 yaitu: Tenaga kependidikan bertugas melaksanakan administrasi, pengelolaan, pengembangan, pengawasan, dan pelayanan teknis untuk menunjang proses pendidikan pada satuan pendidikan.

Tenaga kependidikan meliputi kepala sekolah/madrasah, pengawas satuan pendidikan, tenaga administrasi, tenaga perpustakaan, tenaga laboratorium, teknisi, pengelola kelompok belajar, pamong belajar, dan tenaga kebersihan.

Tenaga Kependidikan lainnya

- Orang yang berpartisipasi dalam penyelenggaraan pendidikan di satuan pendidikan, walaupun secara tidak langsung terlibat dalam proses pendidikan, diantaranya: 
- Wakil-wakil/Kepala urusan umumnya pendidik yang mempunyai tugas tambahan dalam bidang yang khusus, untuk membantu Kepala Satuan Pendidikan dalam penyelenggaraan pendidikan pada institusi tersebut. Contoh: Kepala Urusan Kurikulum

- Tata usaha, adalah Tenaga Kependidikan yang bertugas dalam bidang administrasi instansi tersebut. Bidang administrasi yang dikelola diantaranya; surat menyurat dan pengarsipan, Kepegawaian, Peserta Didik, Keuangan, Inventaris dan lain-lain.

- Laboran, adalah petugas khusus yang bertanggung jawab terhadap alat dan bahan di Laboratorium.

- Pustakawan (lihat perpustakaan)

- Pelatih ekstrakurikuler,

- Petugas keamanan (penjaga sekolah), Petugas kebersihan, dan lainya.

Berdasarkan uraian diatas maka dapat disimpulkan bahwa administrasi pendidik dan tenaga kependidikan adalah proses keseluruhan kegiatan pendidik yang meliputi perencanaan, pengorganisasian, pengarahan, pelaporan, pengkoordinasian, pengawasan dan pembiayaan, dengan menggunakan atau memanfaatkan fasilitas yang tersedia, baik personil, materiil, maupun spirituil untuk mencapai tujuan pendidikan secara efektif dan efisien.

\section{B. Administrasi Peserta didik}

Pengelolaan peserta didik menurut Hendayat Soetopo dan Wasty Soemanto (1982) adalah merupakan suatu penataan atau pengaturan segala aktivitas yang berkaitan dengan peserta didik, yaitu dari mulai masuknya peserta didik sampai dengan keluarnya peserta didik tersebut dari suatu sekolah atau suatu lembaga. 
Dengan demikian pengelolaan peserta didik itu bukanlah dalam bentuk pencatatan/pengelolaan data peserta didik saja, melainkan meliputi aspek yang lebih luas, yang secara operasional dapat dipergunakan untuk membantu kelancaran upaya pertumbuhan dan perkembangan peserta didik melalui proses pendidikan di sekolah.

1. Rekrutmen Peserta Didik

Adapun tugas dari panitia ini adalah mengadakan pendaftaran calon peserta didik, seleksi, pendaftaran kembali peserta didik yang diterima dan melaporkan pertanggungjawaban pelaksanaan penerimaan calon peserta didik kepada Kepala Sekolah yang selanjutnya dilaporkan ke Kantor Wilayah. Untuk lebih jelasnya dapat dideskripsikan sebagai berikut :
a. Pendaftaran
b. Syarat-syarat Pendaftaran
c. Seleksi. Seleksi diadakan apabila sekolah-sekolah yang jumlah pendaftarnya melebihi daya tampung yang tersedia.
d. Pengumuman dan daftar ulang
e. Orientasi calon peserta didik

2. Penempatan peserta didik

Sebelum peserta didik yang telah diterima mengikuti kegiatan belajar, terlebih dahulu perlu ditempatkan dan dikelompokkan dalam kelompok belajarnya.

Menurut William A. Jeager yang diperhatikan dalam pengelompokkan belajar yaitu : 
a. Fungsi integrasi yaitu dalam pengelompokkan peserta didik menurut umur, jenis kelamin, dan sebagainya.

b. Fungsi perbedaan, yaitu dalam pengelompokkan peserta didik berdasarkan pada perbedaan individu, misalnya: bakat, kemampuan, minat dan sebagainya.

Dasar-dasar pengelompokkan peserta didik ada lima macam, sebagai berikut :

a. Friendship Grouping. Pengelompokkan peserta didik berdasarkan kesukaan di dalam memilih teman diantaranya peserta didik itu sendiri.

b. Achievement Grouping. Pengelompokkan belajar dalam hal ini adalah campuran antara peserta didik yang berprestasi tinggi dan peserta didik yang berprestasi rendah.

c. Aptitude Grouping. Pengelompokkan peserta didik berdasarkan atas kemampuan dan bakat yang sesuai dengan apa yang dimiliki oleh peserta didik itu sendiri.

d. Attention or Interest Grouping. Pengelompokkan peserta didik berdasarkan atas perhatian atau minat yang didasari oleh kesenangan peserta didik itu sendiri.

e. Intelligence Grouping. Pengelompokkan yang didasarkan atas hasil test intelegensi yang diberikan kepada peserta didik.

3. Pembinaan Peserta Didik

Keberhasilan kemajuan belajar peserta didik serta prestasi yang ditempuh peserta didik, memerlukan data otentik yang dapat dipercaya serta memiliki keabsahan. Karena kemajuan peserta didik merupakan faktor yang sangat vital bagi kebutuhan perkembangan berlangsungnya proses pendidikan. Salah satu 
tujuan pendidikan adalah menghasilkan para lulusan yang berkualitas. Tinggi rendahnya kualitas pendidikan dipengaruhi oleh beberapa faktor. Salah satu faktor pengaruh itu adalah penilaian yang dilakukan oleh para guru atau lembaga kependidikan. Berarti pula bahwa penilaian-penilaian menurut keobjektifan dari penilai.

Nilai kemajuan peserta didik dilakukan dengan cara mengisi buku laporan pendidikan atau raport. Isi dari raport tersebut adalah nilai-nilai bidang studi yang dipelajari peserta didik sesuai dengan petunjuk kurikulum yang sudah diprogramkan bagi tujuan masing-masing lembaga pendidikan.

Raport yang berisikan kemajuan peserta didik mempunyai arti yang sangat penting bagi kontrol kemajuan prestasi belajar peserta didik selama berada di sekolah tersebut, sampai peserta didik itu tamat dan melanjutkan ke sekolah/jenjang pendidikan yang lebih tinggi.

a. Pencatatan dan Pelaporan Kemajuan Peserta Didik

Pencatatan dan pelaporan tentang di sekolah sangat diperlukan sejak diterima di sekolah itu sampai mereka tamat atau meninggalkan sekolah tersebut. Untuk itu diperlukan beberapa peralatan dan perlengkapan yang dapat dipergunakan sebagai alat bantu dalam pencatatan dan pelaporan tersebut.

Peralatan dan perlengkapan yang diperlukan itu berupa :

1) Buku induk

Buku ini disebut juga buku pokok atau stambuk. Buku ini berisi catatan tentang peserta didik yang masuk pada sekolah tersebut. Setiap pencatatan peserta didik disertai dengan nomor pokok/stambuk, dan dilengkapi pula dengan data-data lain setiap peserta didik.

2) Buku klapper 
Pencatatan buku ini dapat diambil dari buku induk, tetapi penulisannya disusun berdasarkan abjad. Hal ini untuk memudahkan pencarian data peserta didik kembali jika sewaktu-waktu diperlukan.

3) Daftar presensi

Daftar hadir peserta didik sangat penting sebab frekuensi kehadiran setiap peserta didik dapat diketahui/dikontrol. Untuk memeriksa kehadiran peserta didik pada keseluruhan kegiatan di sekolah, setiap hari biasanya daftar kehadiran itu dipegang oleh petugas khusus. Sedangkan untuk memeriksa kehadiran peserta didik di kelas pada jam-jam pelajaran, daftar hadir itu dipegang oleh guru.

4) Daftar mutasi peserta didik

Untuk mengetahui keadaan jumlah pesrta didik dengan persis, sekolah harus mempunyai buku/daftar mutasi peserta didik. Daftar mutasi itu digunakan untuk mencatat ke luar masuk peserta didik dalam setiap bulan, semester atau setahun. Hal ini karena keadaan jumlah peserta didik tidak tetap, ada peserta didik pindahan dan ada pula peserta didik yang keluar.

5) Buku catatan pribadi peserta didik

Buku catatan peserta didik ini lebih lengkap lagi tentang data setiap peserta didik. Buku ini antara lain berisi : identitas peserta didik, keterangan mengenai keadaan keluarga, keadaan jasmani dan kesehatan, riwayat pendidikan serta hasil belajar, data psikologis (sikap, minat, dan cita-cita) dan juga kegiatan di luar sekolah. Buku ini biasanya disimpan di ruang BP dan dikerjakan pula oleh petugas BP.

6) Daftar nilai 
Daftar nilai ini dimiliki oleh setiap guru bidang studi, khusus untuk mencatat hasil tes setiap peserta didik pada bidang studi/mata pelajaran tertentu. Dalam daftar nilai ini dapat diketahui kemajuan belajar peserta didik, karena setiap nilai hasil tes dicatat di dalamnya. Nilai-nilai tersebut sebagai bahan olahan nilai raport.

7) Legger

Legger merupakan kumpulan nilai dari seluruh bidang studi untuk setiap peserta didik. Pengisian/pencatatan nilai-nilai dalam legger ini dikerjakan oleh wali kelas sebagai bahan pengisian rapor. Pencatatan nilai-nilai dalam legger untuk tingkat SD satu tahun tiga kali dan untuk tingkat SLTP/SLTA satu tahun dua kali.

8) Buku Rapor

Buku rapor merupakan alat untuk melaporkan prestasi belajar perta didik kepada orang tua/ wali atau kepada peserta didik itu sendiri. Selain prestasi belajar, dilaporkan pula tentang kehadiran, tingkah laku peserta didik dan sebagainya. Buku ini diberikan tiga kali dalam satu tahun untuk tingkat SD dan dua kali untuk tingkat SLTP/SLTA.

b. Organisasi Peserta Didik Intra Sekolah (OSIS)

OSIS merupakan wadah untuk menampung dan menyalurkan serta mengembangkan kreatifitas peserta didik, baik melalui kegiatan kurikuler maupun ekstrakuriluler dalam rangka menunjang keberhasilan kurikuler.

Dengan adanya organisasi ini, diharapkan sekolah akan merupakan suatu Wiyatamandala (lingkungan pendidikan), yaitu lingkungan dengan suasana belajar mengajar yang efektif dan efisien, yang tergambar dalam hubungan yang harmonis antara guru dengan peserta didik, peserta didik 
dengan peserta didik, demikian pula antara guru dengan guru dan antara peserta didik dengan orang tua

c. Layanan-Layanan Khusus yang Menunjang Kelancaran Pengelolaan Peserta Didik

1). Bimbingan di Sekolah

Fungsi bimbingan di sekolah ada tiga yaitu :

- Fungsi menyalurkan, yaitu membantu peserta didik dalam memilih jenis sekolah lanjutannya, memilih program, memilih lapangan pekerjaan sesuai dengan bakat, minat, kemampuan dan cita-citanya.

- Fungsi mengadaptasikan, yaitu membantu guru atau tenaga edukatif lainnya untuk menyesuaikan program pengajaran dengan minat, kemampuan, dan cita-cita peserta didik.

○ Fungsi menyesuaikan, yaitu membantu peserta didik dalam menyesuaikan diri dengan bakat, minat, dan kemampuannya untuk mencapai perkembangan yang optimal.

Ruang lingkup bimbingan di sekolah yaitu :

a) Layanan kepada peserta didik

Dilihat dari jenis permasalahan yang dihadapi peserta didik, mencakup : bimbingan pribadi, bimbingan sosial, bimbingan pendidikan, bimbingan pekerjaan (bimbingan karir).

Dilihat dari urutan kegiatan, mencakup : layanan orientasi, layanan pengumpulan data pribadi, layanan pemberian informasi, layanan penempatan, layanan penyuluhan, layanan pengiriman (referal), layanan tindak lanjut.

b) Layanan kepada guru

c) Layanan kepada kepala sekolah 

d) Layanan kepada calon peserta didik (feeder school)
e) Layanan kepada orang tua
f) Layanan kepada dunia kerja, terutama dilaksanakan di sekolah kejuruan
g) Layanan kepada lembaga-lembaga dan masyarakat lain

\section{2). Perpustakaan Sekolah}

Perpustakaan sekolah merupakan peringkat kelengkapan pendidikan dalam mencapai tujuan umum pendidikan nasional.

Tujuan perpustakaan sekolah :

Mengembangkan minat, kemampuan dan kebiasaan membaca khususnya serta mendayagunakan budaya tulisan;

Mendidik peserta didik agar mampu memelihara dan memanfaatkan bahan pustaka secara efektif dan efisien; Meletakkan dasar kearah belajar mandiri;

Memupuk bakat dan minat;

Mengembangkan kemampuan untuk memecahkan masalah yang dihadapi dalam kehidupan sehari-hari atas usaha dan tanggung jawab sendiri.

Perpustakaan sekolah diselenggarakan di setiap sekolah. Penyelenggaranya adalah guru yang ditunjuk oleh kepala sekolah baik sebagai ahli perpustakaan atau guru yang ditugaskan di perpustakaan dan telah mendapat kursus/latihan sebelumnya.

Layanan perpustakaan bertujuan untuk menyajikan informasi untuk peningkatan proses belajar mengajar serta rekreasi bagi semua warga sekolah dengan mempergunakan bahan pustaka.

Secara operasional layanan perpustakaan terdiri dari layanan sirkulasi, referensi,dan bimbingan membaca. 
Ada tiga jenis layanan perpustakaan sesuai dengan sasaran yang ditujunya yaitu :

a) Layanan kepada guru, meliputi kegiatan berikut :

Meningkatkan pengetahuan guru mengenai subyek yang menjadi bidang.

Membantu guru dalam mengajar di kelas dengan menyediakan alat audio-visual dan lain-lain;

Menyediakan bahan pustaka pesanan yang diperlukan mata pelajaran tertentu;

Menyediakan bahan informasi bagi kepentingan penelitian yang diperlukan oleh guru dalam rangka meningtkan profesinya;

Untuk SD menyediakan jam bercerita, pembacaan buku, dan permainan boneka;

Mengisi jam pelajaran yang kosong;

b) Layanan kepada peserta didik, meliputi :

Menyediakan bahan pustaka yang memperkaya dan memperluas cakrawala kurikulum;

Menyediakan bahan pustaka yang dapat membantu peserta didik memperdalam pengetahuannya mengenai subyek yang diminatinya;

Menyediakan bahan untuk meningkatkan ketrampilan;

Menyediakan kemudahan untuk untuk membantu peserta didik mengadakan penelitian;

Meningkatkan minat baca peserta didik dengan cara mengadakan bimbingan membaca, bagaimana menggunakan perpustakaan, mengenalkan jenis-jenis koleksi, buku, bercerita, membaca keras, membuat isi ringkas, kliping dan lain-lain.

c) Layanan terhadap manajemen sekolah. 
Perpustakaan secara aktif membantu pimpinan sekolah dan guru dalam bidang perencanaan dan pelaksanaan, pemanduan dan penilaian program pendidikan di sekolah. Organisasi dan tata laksana perpustakaan sekolah adalah :

- Sebagai perangkat pendidikan di sekolah, perpustakaan merupakan bagian integral dari sekolah. Perpustakaan berfungsi sebagai pusat belajar dan mengajar, pusat informasi, pusat penelitian sederhana dan rekreasi sehat

- Sebagai unit pelaksana teknis, perpustakaan sekolah dipimpim oleh seorang kepala pepustakaan yang di bawah dan bertanggung jawab kepada kepala sekolah. Perpustakaan sekolah melaksanakan kegiatan teknis yang mencakup keadaan, pengolahan, penyusunan buku dan katalog. Sedangkan kegiatan layanan sirkulasi, layanan buku rujukan dan layanan baca

- Sebagai Mata rantai dalam sistem nasional layanan perpustakaan, dalam rangka meningkatkan kemampuan menyediakan bahan-bahan yang dibutuhkan, perpustakaan dapat melakukan kerja sama dengan perpustakaan lain. Koleksi perpustakaan sekolah terutama terdiri dari bahan pustaka yang menjadi bahan pokok dan penunjang kurikulum sekolah yang sesuai dengan jenis dan jenjangnya.

Jenis koleksi perpustakaan sekolah terdiri dari :

1) Bahan cetak seperti buku, majalah, surat kabar, brosur, pamflet, guntingan surat kabar, majalah, dan sebagainya.

2) Bahan bukan cetak, seperti karya tulis guru dan murid, 
peta gambar, globe, relif, slide, film, pita rekaman, dan sebagainya.

Menurut isi/cakupannya, koleksi perpustakaan sekolah yang berupa buku, terdiri atas : buku-buku teks, bukubuku teks pelengkap, buku-buku rujukan seperti kamus, ensiklopedia, almanak, buku tahunan, terbitan pemerintah, buku-buku bacaan fiksi/rekaan dan sebagainya.

Perbandingan koleksi antara buku non fiksi dan fiksi disarankan sebagai berikut : untuk SD 60:40, untuk SMP 70:30, untuk SLTA 75:25.

Jumlah koleksi dasar disarankan dengan perbandingan 10 judul buku untuk seorang murid. Koleksi dasar $50 \%$ dari jumlah koleksi minimal. Selanjutnya untuk pengembangan, diperlukan setiap tahun penambahan koleksi kurang lebih $10 \%$ dari jumlah koleksi yang ada. Selanjutnya diperlukan $10 \%$ lagi untuk pemeliharaan dan penggantian.

Sebelum siap dipinjamkan, bahan pustaka perlu diorganisasikan/diolah berdasarkan peraturan dan ketentuan yang telah dibakukan. Untuk klasifikasi digunakan sistem DDC (Dewey Decimal Classification), untuk katalogisasi mempergunakan peraturan katalogisasi Indonesia. Untuk teknis pelaksanaan digunakan pedoman penyelenggaraan perpustakaan sekolah.

d. Usaha Kesehatan Sekolah (UKS)

Usaha kesehatan sekolah adalah usaha kesehatan masyarakat yang dijalankan di sekolah. Sasaran utama UKS adalah untuk meningkatkan atau membina kesehatan murid dan lingkungan hidupnya. Program Usaha Kesehatan Sekolah adalah sebagai berikut : 
Mencapai lingkungan hidup yang sehat, Pendidikan kesehatan,

Pemeliharaan kesehatan di sekolah. Gedung sekolah merupakan tempat para peserta didik belajar dan menghabiskan sebagian waktunya. Karena itu sekolah hendaknya memenuhi persyaratan "school Plant", misalnya gedung sekolah harus ditanami rumput, air yang bersih, WC tersedia dan memenuhi persyaratan serta dibersihkan setiap hari, ruangan kelas harus bersih dan nyaman. Inilah yang dimaksud dengan mencapai lingkungan hidup di sekolah.

Pendidikan kesehatan dimulai dengan cara memberikan informasi bahwa kebiasaan hidup sehat merupakan modal utama dalam kehidupan misalnya tempat tinggal yang sehat, mandi dua kali sehari, makanan bergizi, dan sebagainya.

Peranan guru sangat besar dalam pendidikan kesehatan. Guru harus menegur peserta didiknya yang berpakaian dan berbadan kotor, sewaktu-waktu guru mengajak peserta didik untuk membersihkan lingkungan sekolah/kerja bakti. Pemeriksaan kesehatan umum maupun kursus diadakan secara berkala. Sejak masuk kelas satu hari sudah mulai diajarkan hidup sehat, lingkungan sehat, pemberantasan penyakit, sehingga peserta didik terpelihara kesehatan jasmani dan rohaninya.

Penyelenggara UKS memerlukan kerja sama antara seluruh warga sekolah. Setiap warga sekolah hendaknya menjalankan tugasnya sebaik-baiknya. Kepala sekolah dan para guru sebagai penanggung jawab umum, sedangkan peserta didik membantu pelaksanaan UKS, dengan piket secar bergiliran. Di samping penanggung jawab umum, hendaknya ada penanggung jawab bidang pendidikan kesehatan, bidang kebersihan lingkungan kelas sehat, bidang pemeliharaan (pemeriksaan/pemeliharaan) kesehatan dan 
penanggung jawab mengenai usaha-usah yang dijalankan sekolah (misalnya : kantin sekolah, usaha berternak, bertelur dan lain-lain).

e. Kantin Sekolah

Kantin /warung sekolah diperlukan adanya di tiap sekolah supaya makanan yang dibeli peserta didik terjamin kebersihannya dan cukup mengandung gizi. Para guru diharapkan sekali-kali mengontrol kantin sekolah dan berkonsultasi dengan pengelola kantin mengenai makanan yang bersih dan bergizi. Peranan lain kantin sekolah yaitu supaya para peserta didik tidak berkeliaran mencari makanan keluar lingkungan sekolah.

Pengelola kantin sebaiknya dipegang oleh orang dalam atau keluarga karyawan sekolah yang bersangkutan, agar segala makanan yang dijual di kantin tersebut terjamin dan bermanfaat bagi peserta didik.

f. Transportasi Sekolah

Sarana angkutan (transportasi) bagi para peserta didik merupakan salah satu penunjang untuk kelancaran proses belajar mengajar. Para peserta didik akan merasa aman dan dapat masuk/pulang sekolah dengan waktu yang tepat. Transportasi diperlukan terutama bagi para peserta didik ditingkat prasekolah dan pendidikan dasar. Penyelenggaraan transportasi sebaiknya dilaksanakan oleh sekolah yang bersangkutan atau pihak swasta (misalnya dengan cara abodemen).

g. Peranan Guru dalam Pelayanan Peserta Didik

Guru merupakan sumber daya manusia yang potensial bagi pengembangan kreativitas peserta didik dalam berbagai aspek. Salah satu tugas utama guru adalah membentuk anak didik mencapai kewaspadaannya masing-masing. Hal inipun merupakan salah satu ciri keberhasilan tujuan pendidikan 
yang dipengaruhi oleh berbagai faktor, diantaranya yaitu faktor penyelenggara pendidikan, guru, peserta didik, sarana dan fasilitas belajar mengajar, kurikulum sebagai pedoman dasar bagi terselenggaranya tujuan pendidikan.

Partisipasi guru dalam pelayanan peserta didik menduduki teratas, artinya setiap guru harus memahami fungsi terhadap pelayanan peserta didik. Beberapa hal yang perlu diperhatikan dalam pelayanan peserta didik di sekolah, sebagai berikut :

- Kehadiran peserta didik dan masalah-masalahnya;

- Penerimaan, orientasi, klasifikasi dan petunjuk bagi peserta didik baru tentang kelas dan program studi;

- Evaluasi dan pelaporan kemajuan peserta didik.

- Program bagi peserta didik yang mempunyai kelainan, seperti pengajaran perbaikan dan pengajar luar biasa.

- Pengendalian disiplin peserta didik

- Program bimbingan dan penyuluhan;

- Program kesehatan dan pengaman; dan Penyesuaian pribadi, sosial dan emosional peserat didik.

4. Disiplin Kelas

Di dalam pembicaraan disiplin, dikenal dua istilah yang pengertiannya hampir sama tetapi terbentuknya satu sama lain merupakan urutan. Kedua istilah itu adlah disiplin dan ketertiban. Diantara kedua istilah tersebut terleih dahulu terbentuk pengertian ketertiban, baru kemudian pengertian disiplin. Ketertiban menunjuk pada kepatuhan seseorang dalam mengikuti peraturan atau tata tertib karena didorong oleh sesuatu yang datangdari luar. Sedangkan disiplin menunjuk pada kepatuhan seseorang dalam mengikuti peraturan atau tata tertib karena didorong oleh adanya kesadaran yang ada pada 
kata hatinya. Dengan demikian, disiplin kelas adalah keadaan tertib dalam suatu kelas yang di dalamnya tergabung guru dan siswa taat kepada tata tertib yang telah ditetapkan.

Dengan disiplin para siswa bersedia untuk tunduk dan mengikuti peraturan tertentu dan menjauhi larangan tertentu. Kesediaan semacam ini harus dipelajari dan harus secara sabar diterima dalam rangka memelihara kepentingan bersama atau memelihara kelancaran tugas- tugas sekolah.

Satu keuntungan lain dari adanya displin adalah siswa belajar hidup dengan pembiasaan yang baik, positif dan bermanfaat bagi dirinya dan lingkungannya.

Menegakkan disiplin tidak bertujuan untuk mengurangi kebebasan dan kemerdekaan siswa akan tetapi sebaliknya ingin memberikan kemerdekaan yang lebih besar kepada siswa dalam batas-batas kemampuannya. Akan tetapi juga kalau kebebasan siswa terlampau dikurangi atau dikekang dengan peraturan maka siswa akan berontak dan mengalami frustasi dan kecemasan. Di sekolah, disiplin banyak digunakan untuk mengontrol tingkah laku siswa yang dikehendaki agar tugastugas sekolah dapat berjalan dengan optimal.

5. Penanggulangan Pelanggaran disiplin

Penanggulangan pelanggaran disiplin kelas perlu dilaksanakan secara penuh kehati- hatian, demokratis dan edukatif. Cara-cara penanggulangan dilaksanakan secara bertahap dengan tetap memperhatikan jenis gangguan yang ada dan siapa pelakunya, apakah dilakukan oleh individu atau kelompok. Langkah tersebut mulai dari tahapan pencegahan sampai pada tahapan penyembuhan, dengan tetap bertumpu penekanan substansinya bukan pada pribadi peserta didik. Disamping itu juga harus tetap menjaga perasaan kecintaan terhadap peserta 
didik bukan karena rasa benci atau emosional. Namun demikian perlu disadari benar bahwa disiplin di kelas sangat dipengaruhi oleh berbagai faktor, diantaranya faktor lingkungan siswa seperti lingkunga rumah. Oleh karena itu, guru juga perlu menjalin kerja sama dengan orang tua siswa, agar kebiasaan disiplin di sekolah yang hendak dipelihara itu semakin tumbuh subur. Di bawah ini dikemukakan tiga jenis teknik pembinaan disiplin kelas :

Teknik "Inner Control", teknik ini sangat disarankan untuk digunakan guru-guru dalam membina disiplin peserta didiknya.Teknik ini menumbuhkan kepekaan/penyadaran akan tata tertib dan pada akhirnya disiplin harus tumbuh dan berkembang dari dalam peserta didik itu sendiri (self dicipline) Dengan kata lain peserta didik diharapkan dapat mengendalikan dirinya sendiri.

Teknik "External control", teknik external control yaitu mengendalikan diri dari luar berupa bimbingan dan penyuluhan. Teknik ini dalam menumbuhkan disiplin cenderung melakukan "pengawasan" (yang kadang perlu diperketat dan kalau perlu menjatuhkan hukuman terhadap setiap pelanggaran).

Teknik "Cooperative control", dengan teknik ini, pembinaan disiplin kelas dilakukan dengan bekerja sama guru dengan peserta didik dalam mengendalikan situasi kelas ke arah terwujudnya tujuan kelas yang bersangkutan. Dimana guru dan peserta didik saling mengontrol satu sama lain terhadap pelanggaran tata tertib.

Yang perlu diperhatikan oleh guru dalam proses pembinaan disiplin kelas adalah perbedaan-perbedaan individual peserta didik dalam kesanggupan mengadakan mawas diri (instropeksi) dan pengendalian dirinya (self control). Karena itu teknik cooperative control sangat dianjurkan untuk menetralisir teknik 
inner control (yang menuntut kedewasaan) dan ekternal control (yang menganggap peserta didik belum dewasa).

\section{Administrasi Kurikulum}

Istilah kurikulum pada awalnya bukan dipakai dalam dunia pendidikan, yaitu dipakai sebagai istilah dalam dunia olahraga. Dalam buku Asas_asas Kurikulum, S. Nasution menyebutkan bahwa dala dalam kamu Webster kata kurikulum timbul untuk pertama kalinya pada tahun 1856, yaitu " a race course a place for running a chariot" yang artinya suatu jarak yang harus ditempuh oleh pelari atau kereta dalam perlombaan dari awal sampai akhir.

Kurikilum juga berarti "chariot" yakni suatu alat yang membawa seseorang dari start sampai finish. Disamping itu, pengguna kurikulum yang semula dalam bidang olahraga, kemudian dipakai dalam bidang pendidikan bidang pendidikan, yang dalam kamus webster disebut "applied particulary to the course of study in a university" kemudian Nasution menambahkan bahwa pada tahun 1955 dalam kamus Webster kurikulum diberi arti "sejumlah mata pelajaran disekolah atau mata kuliah di perguruan tinggi, yang harus ditempuh untuk mencapai suatu ijazah atau tingkat. Juga berarti keseluruhan pelajaran yang disajikan oleh suatu lembaga pendidikan.

Dengan mengacu pada definisi klasik di atas, yang mengemukakan bahwa kurikulum hanya terbatas pada mata pelajaran saja, berarti ada beberapa kegiatan dan pengalaman murid yang tidak cocok dengan batasan kurikulum ini. Kegiatan-kegiatan yang disebut ekstrakurikuler (extra curiculer activities) berada di luar kurikulum, jadi pengalaman-pengalaman di sekolah tidak termasuk di dalamnya. Pengalaman-pengalaman seperti bermain di halaman sekolah, jalan, istirahat dan lain-lain sejenisnya tidak termasuk kurikulum, dianggap bukan pengalaman belajar. 
Di samping hal di atas, menurut Murni Yusuf yang mengutip pendapat Nana Syaodih, bahwa terdapat tiga konsep yang terkait dengan kurikulum :

1. Kurikulum merupakan inti pokok yang menjadi substansi kegiatan di sekolah.

Kurikulum berisi perencanaan kegiatan belajar serta tujuan yang akan dicapai.

2. Kurikulum dipandang sebagai suatu sistem yang meliputi sistem sekolah, sistem pendidikan dan bahkan sistem masyarakat. Dalam hal ini, tercakup tata laksana perencanaan kurikulum, pelaksanaan serta evaluasi dan penyempurnaan kurikulum.

3. Kurikulum sebagai suatu studi yang dikaji oleh para ahli di bidang kurikulum. Dalam kaitan ini, para ahli kurikulum berupaya melakukan pengembangan dan inovasi di bidang kurikulum.

Saat ini para pemuka pendidikan menonjolkan kenyataan bahwa belajar pada tiap anak merupakan proses yang berlangsung selama 24 jam tiap hari. Mereka berpendapat pengalaman-pengalaman dalam perkumpulan kesenian dan olah raga disekolah dalam darmawisata dan lain-lain, kesemuanya merupakan situasi-situasi belajar yang kaya akan pendidikan. Karena kurikulum meliputi segala pengalaman yang sengaja diberikan sekolah untuk memupuk perkembangan anak-anak dengan jalan menciptakan situasi belajar-mengajar

Komponen Kurikulum

Mengingat bahwa fungsi kurikulum dalam proses pendidikan adalah sebagai alat untuk mencapai tujuan pendidikan, maka hal ini berarti bahwa sebagai alat pendidikan, kurikulum memiliki bagianbagian penting dan penunjang yang dapat mendukung operasinya dengan baik. Bagian-bagian ini disebut komponen yang saling berkaitan berinteraksi dalam upaya mencapai tujuan. 
Menurut Hasan Langgulung ada 4 komponen utama kurikulum, yaitu :

- Tujuan-tujuan yang ingin dicapai oleh pendidikan itu. Dengan lebih tegas lagi orang yang bagaimana yang ingin kita bentuk dengan kurikulum tersebut.

- Pengetahuan (knowledge), informasi-informasi, data-data, aktifitas-aktifitas dan pengalaman-pengalaman dari mana terbentuk kurikulum itu. Bagian inilah yang disebut mata pelajaran.

- Metode dan cara-cara mengajar yang di pakai oleh guru-guru untuk mengajar dan memotivasi murid untuk membawa mereka kea rah yang dikahendaki oleh kurikulum.

- Metode dan cara penilaian yang dipergunakan dalam mengukur dan menilai kurikulum dan hasil proses pendidikan yang direncanakan kurikulum tersebut.

Fungsi Administrasi Kurikulum

Dalam proses pendidikan perlu dilaksanakan administrasi kurikulum agar perencanaan, pelaksanaan, dan evaluasi kurikulum berjalan lebih efektif, efisien dan optimal dalam memberdayakan berbagai sumber belajar, pengalaman belajar maupun komponen kurikulum. Ada beberapa fungsi dari administrasi kurikulum diantaranya:

- Meningkatkan efisien pemanfaatan sumber daya kurikulum, pemberdayaan sumber maupun komponen kurikulum dapat ditingkatkan melalui pengelolaan yang terencana dan efektif.

- Meningkatkan keadilan (equity) dan kesempatan pada siswa untuk mencapai hasil yang maksimal, kemampuan yang maksimal dapat dicapai peserta didik tidak hanya melalui kegiatan intrakurikuler, tetapi juga perlu melalui kegiatan ekstrakurikuler yang di kelola secara integritas dalam mencapai tujuan kurikulum. 
- Meningkatkan relecansi dan efektifitas pembelajaran sesuai dengan kebutuhan peserta didik maupun lingkungan sekitar peserta didik, kurikulum yang dikelola secara efektif dapat memberika kesempatan dan hasil yang relevan dengan kebutuhan peserta didik maupun lingkungan sekitar.

- Meningkatkan efektivitas kinerja guru maupun aktivitas siswa dalam mencapai tujuan pembelajaran, pengelolaan kurikulum yang profesional, efektif dan terpadu dapat memberikan motivasi pada kinerja guru maupun aktivitas sisiwa dalam belajar.

- Meningkatkan efisien dan efektivitas proses belajar, proses pembelajaran selalu dipantau dalam rangka melihat konsistensi antara desain yang telah direncanakan dengan pelaksanaan pembelajaran. Dengan demikian, ketidaksesuaiaan antara desain dengan implementasi dapat dihindarkan. Disamping itu, guru maupun siswa selalu termotivasi untuk melaksanakan pembelajaran yang efektif dan efisien karena adanya dukungan kondisi positif yang diciptakan dalam kegiatan pengelolahan kurikulum.

- Menigkatkan partisipasi masyarakat untuk membantu mengembangkan kurikulum. Kurikulum yang dikelola secara profesional akan melibatkan masyarakat khususnya dalam mengisi bahan ajar atau sumber belajar perlu disesuaikan dengan ciri khas dan kebutuuhan pembangunan daerah setempat.

Prinsip Pembinaan dan Pengembangan Kurikulum

Kurikulum dibina dan dikembangkan berdasarkan pada prinsipprinsip yang dianutnya. Prinsip itu pada dasarnya merupakan kaidah yang menjiwai kurikulum tersebut. Prinsip-prinsip yang biasa digunakan dalam suatu pengembangan kurikulum. Menurut Sudirman S, antara lain: 


\section{a. Prinsip Orientasi Pada Tujuan}

Implikasi prinsip ini mengusahakan agar seluruh kegiatan kurikuler terarah dan diarahkan untuk mencapai tujuan pendidikan yang telah dirumuskan sebelumnya.

b. Prinsip Relevansi

Secara umum istilah relevansi diartikan sebagai kesesuaian atau keserasian pendidikan dengan tuntunan kehidupan masyarakat. Artinya pendidikan dipandang relevan jika hasil perolehan pendidikan itu bersifat fungsional. Masalah relevansi ini dapat dikaji sekurang-kurangnya lewat tiga segi:

1. Relevansi pendidikan dengan lingkungan para murid. Artinya dalam penetapan bahan pendidikan yang akan disajikan haruslah sesuai dengan apa yang ada dalam lingkungan sekitar murid.

2. Relevansi dengan pengembangan kehidupan masa kini dan masa yang akan datang. Misalnya topik sajian "pembuatan kipas dari bambu" untuk penduduk kota, kiranya kurang tepat sebab di kota sekarang ini memasak menggunakan kompor minyak atau kompor gas yang tidak memerlukan kipas dari bambu.

3. Relevansi dengan tuntutan dalam dunia pekerjaan. Dalam menetapkan kegiatan belajar dan pengalaman belajar siswa hendaknya diorientasikan dengan tuntutan dalam dunia pekerjaan atau konsumen pemakai lulusan atau konsumennya nanti. Misalnya para murid SMEA harus banyak diajarkan surat-menyurat, mengetik komputer, dan lain-lain sesuai dengan apa yang diharapkan oleh pemakai lulusan atau konsumennya nanti.

c. Prinsip Efektifitas

Implikasi prinsip ini dalam pengembangan kurikulum ialah mengusahakan agar setiap kegiatan kurikuler membuahkan hasil tanpa ada kegiatan yang mubazir dan terbuang percuma.

d. Prinsip Efisiensi

Implikasi prinsip ini mengusahakan agar kegiatan kurikuler mendayagunakan waktu, tenaga, biaya dan sumber-sumber lain 
secara cermat dan tepat sehingga hasil kegiatan kurikuler itu mewadahi dan memenuhi harapan.

e. Prinsip Fleksibilitas

Fleksibilitas ini diartikan lentur/tidak kaku dalam memberikan kebebasan bertindak. Dalam kurikulum pengertian itu dimaksudkan dalam memilih program-program pendidikan bagi murid dan kebebasan dalam mengembangkan program pendidikan bagi para guru. Misalnya pengadaan program pilihan yang sesuai dengan kemampuan dan minat murid.

f. Prinsip Integritas

Implikasi prinsip ini mengusahakan agar pendidikan dalam suatu kurikulum menghasilkan manusia seutuhnya walaupun kegiatan kurikulernya terjabar dalam komponen kurikulum.

g. Prinsip Sinkronisasi

Implikasi prinsip ini mengusahakan agar seluruh kegiatan kurikuler seirama, searah dan satu tujuan. Jangan sampai terjadi suatu kegiatan kurikuler menghambat, berlawanan atau mematikan kegiatan-kegiatan kurikuler lainnya.

h. Prinsip kesinambungan (kontinuitas)

Implikasi prinsip ini mengusahakan agar antara berbagai tingkat dari jenis program pendidikan saling berhubungan. Dalam tatanan bahan kurikuler yang dikaitkan atau saling menjalin.

1. Kesinambungan antar berbagai tingkat sekolah. Ada beberapa hal yang perlu diperhatikan:

2. Bahan-bahan pelajaran hendaknya sambung-menyambung antara tingkat yang satu dengan tingkat yang lain yang lebih tinggi.

3. Bahan pelajaran yang sudah disajikan pada tingkat sekolah yang lebih rendah tidak perlu lagi disajikan pada tingkat sekolah yang lebih tinggi. 
4. Kesinambungan antara berbagai tingkat studi. Seringkali bahan sajian dalam berbagai bidang studi mempunyai hubungan yang satu dengan yang lain.

i. Objektifitas

Implikasi prinsip ini mengusahakan agar semua kegiatan kurikuler dilakukan dengan kegiatan catatan kebenaran ilmiah dengan mengenyampingkan pengaruh-pengaruh emosional dan irisional.

j. Prinsip Demokrasi

Implikasi prinsip ini ialah mengusahakan agar dalam penyelenggaraan pendidikan dikelola dan dilaksanakan secara demokrasi.

\section{Administrasi Sarana dan Prasarana}

Suharsimi Arikunto dan Lia Yuliana (2008), "Sarana pendidikan merupakan fasilitas yang diperlukan dalam proses belajar mengajar, baik yang bergerak maupun tidak bergerak agar pencapaian tujuan pendidikan dapat berjalan dengan lancar, teratur dan efisien".

Menurut Mulyasa (2003) sarana pendidikan adalah peralatan dan peralatan yang secara langsung dipergunakan dan menunjang proses pendidikan

Dalam upaya meningkatkan kualitas pendidikan banyak aspek yang mempengaruhi kualitas pendidikan. Salah satu yang dapat mempengaruhi mutu pendidikan yaitu administrasi sarana dan prasarana pendidikan di sekolah. Aspek administrasi sarana dan prasarana pendidikan di sekolah merupakan salah satu dasar yang sangat penting dan harus dapat dimengerti oleh setiap lembaga penyelenggaraan pendidikan dan pendidiknya. Pendidikan formal memerlukan pengaturan dan pengelolaan yang baik agar tujuan pendidikan di sekolah dapat tercapai secara optimal. 
Sarana merupakan peralatan dan perlengkapan yang secara langsung digunakan untuk menunjang proses belajar mengajar seperti buku pelajaran, kursi dan meja sedangkan prasarana merupakan kelengkapan yang secara tidak langsung digunakan dalam menunjang kegiatan belajar mengajar seperti, ruang kelas, ruang laboratorium dan ruang perpustakaan.

Sebagaimana dijelaskan dalam UUD SISDIKNAS No. 20 tahun 2003 tentang standar sarana dan prasarana pasal 42 aya1 1 dan 2 yang menjelaskan setiap satuan pendidikan wajib memiliki sarana seperti perabot, peralatan pendidikan, media pendidikan, buku dan sumber belajar lain yang diperlukan untuk menunjang pembelajaran yang teratur dan berkelanjutan. Dan setiap satuan pendidikan wajib memiliki prasarana yang meliputi lahan, ruang kelas, ruang pimpinan satuan pendidikan, ruang pendidik, ruang tata usaha, ruang perpustakaan, ruang laboratorium, ruang bengkel kerja, ruang unit produksi, ruang kantin, tempat berolahraga dan tempat lain yang diperlukan untuk menunjang proses pembelajaran. Usaha untuk memaksimalkan peran dan fungsi sarana dan prasarana pendidikan adalah dengan memperhatikan kelengkapan sarana dan prasarana serta pengelolaan sarana dan prasarana dalam menunjang kegiatan belajar mengajar.

Adapun beberapa jenis sarana pendidikan menurut beberapa ahli yaitu:

Menurut Nawawi sarana pendidikan diklasifikasikan menjadi tiga, yaitu :

(a) Ditinjau dari habis tidaknya dipakai

(1) Sarana pendidikan yang habis pakai adalah segala bahan atau alat yang apabila digunakan bisa habis dalam waktu yang relatif singkat. Contoh: kapur tulis, 
(2) Sarana pendidikan yang tahan lama adalah keseluruhan bahan atau alat yang dapat digunakan secara terus menerus dalam waktu yang relatif lama. Contoh: meja, kursi, komputer. (b) Ditinjau dari bergerak tidaknya pada saat digunakan

Sarana pendidikan yang bergerak adalah sarana pendidikan yang bisa digerakkan atau dipindahkan sesuai dengan kebutuhan pemakainya. Sarana pendidikan yang tidak bisa bergerak adalah semua sarana pendidikan yang tidak bisa atau relatif sangat sulit dipindahkan. Contoh: penggunaan air pada suatu sekolah.

(c) Ditinjau dari hubungannya dengan proses belajar mengajar

(1) Sarana pendidikan yang secara langsung dapat digunakan dalam proses belajar mengajar. Contoh: kapur tulis, spidol, kertas.

(2) Sarana pendidikan yang tidak secara langsung berhubungan dengan proses belajar mengajar. Contoh: almari arsip.

Menurut Suharsimi Arikunto dan Lia Yuliana (2008), sarana pendidikan dapat diklasifikasikan menjadi dua jenis, yaitu :

(a) Sarana fisik, yakni segala sesuatu yang berupa benda atau fisik yang dapat dibedakan, yang mempunyai peranan untuk memudahkan dan melancarkan suatu usaha. Contoh: mesin ketik, komputer.

(b) Sarana uang, yakni segala sesuatu yang bersifat mempermudah sesuatu kegiatan sebagai akibat bekerjanya nilai uang.

Berdasarkan pendapat tersebut di atas, maka dapat disimpulkan jenis sarana pendidikan dapat dibedakan menjadi peralatan dan perlengkapan sekolah yang dapat digunakan untuk menunjang proses kegiatan belajar mengajar secara langsung di sekolah.

c) Pengertian Prasarana Pendidikan

Untuk menunjang proses belajar mengajar pada sebuah sekolah tidak hanya dibutuhkan sarana tetapi juga prasarana pendidikan agar proses belajar mengajar berjalan dengan efektif 
dan tujuan pendidikan dapat tercapai secara maksimal. Menurut Ibrahim Bafadal (2008), "prasarana pendidikan adalah semua kelengkapan dasar yang secara tidak langsung menunjang pelaksanaan proses pendidikan di sekolah".

Menurut Mulyasa (2003) prasarana pendidikan adalah fasilitas yang secara tidak langsung menunjang jalannya proses pendidikan atau pengajaran.

Berdasarkan pendapat di atas dapat disimpulkan bahwa pengertian prasarana pendidikan adalah semua kelengkapan yang digunakan dan tidak secara langsung menunjang kegiatan belajar mengajar di sekolah. Contoh prasarana pendidikan seperti ruang perpustakaan, ruang laboratorium, ruang kelas, ruang usaha kesehatan sekolah (UKS), kantin, koperasi, kamar mandi, gudang dan tempat parkir kendaraan

Dengan demikian, administrasi sarana dan prasarana pendidikan merupakan segenap proses penataan yang bersangkut paut dengan pengadaan, pendayagunaan dan pengelolaan sarana dan prasarana pendidikan agar tercapai tujuan yang telah ditetapkan secara efektif dan efisien. (Sukirman, 2009)

Administrasi Sarana dan Prasarana Pendidikan merupakan seluruh proses kegiatan yang direncanakan dan diusahakan secara sengaja dan bersungguh-sungguh serta pembinaan secara kontinu terhadap benda-benda pendidikan, agar senantiasa siap pakai dalam proses belajar mengajar sehingga proses belajar mengajar semakin efektif dan efisien guna membantu tercapainya tujuan pendidikan yang telah ditetapkan. (Gunawan, 1996)

Tujuan administrasi sarana dan prasarana pendidikan, antara lain:

1) Untuk mengupayakan pengadaan sarana dan prasarana pendidikan melalui sistem perencanaan dan pengadaan yang hati-hati dan seksama.

2) Untuk mengupayakan pemakaian sarana dan prasarana sekolah secara tepat dan efisien. 
3) Untuk mengupayakan pemeliharaan sarana dan prasarana sekolah, sehingga keberadaannya selalu dalam kondisi siap pakai dalam setiap diperlukan oleh semua personel sekolah. Kegiatan sarana dan prasarana pendidikan meliputi:

1) Perencanaan (kebutuhan dan biaya), dan pengadaan Perencanaan adalah penetapan secara sistematik daripada pengetahuan yang tepat guna untuk mengontrol dan menentukan arah kecenderungan perubahan, menuju kepada tujuan yang ditetapkan.

langkah-langkah perencanaan pengadaan sarana dan prasarana pendidikan di sekolah, yaitu sebagai berikut :

(a) Menampung semua usulan pengadaan sarana dan prasarana sekolah yang diajukan setiap unit kerja sekolah dan atau menginventarisasi kekurangan sarana dan prasarana sekolah.

(b) Menyusun rencana kebutuhan sarana dan prasarana sekolah untuk periode tertentu.

(c) Memadukan rencana kebutuhan yang telah disusun dengan sarana dan prasarana yang telah tersedia sebelumnya.

(d) Memadukanrencanakebutuhandengandanaatau anggaran sekolah yang tersedia.

(e) Memadukan rencana kebutuhan sarana dan prasarana dengan dana atau anggaran yang ada.

(f) Penetapan rencana pengadaan akhir.

2) Penyimpanan dan penyaluran

Penyimpanan merupakan kegiatan menampung hasil pengadaan sarana dan prasarana pendidikan, baik yang belum maupun yang akan didistribusikan. Kegiatan penyimpanan meliputi menerima barang dan mendistribusikan barang. proses ini termasuk di dalamnya adalah kegiatan inventarisasi barang, pengelompokan 
penyimpanan barang serta pendistribusiannya. Barang yang telah diinventarisir dan diatur menurut kelompok penyimpanan selanjutnya dapat disalurkan untuk digunakan kepada pihak yang memerlukan sesuai dengan keperluan dan prosedur yang berlaku

3) Pendayagunaan

4) Pemeliharaan

Ada beberapa macam pemeliharaan sarana dan prasarana pendidikan di sekolah, antara lain :

(1) Ditinjau dari sifat pemeliharaan

(a) Pemeliharaan yang bersifat pengecekan

(b) Pemeliharaan yang bersifat pencegahan

(c) Pemeliharaan yang bersifat perbaikan ringan

(d) Perbaikan berat

(2) Ditinjau dari waktu perbaikannya

(a) Pemeliharaan sehari-hari

(b) Pemeliharaan berkala

Pemeliharaan sarana dan prasarana pendidikan di sekolah, antara lain :

(1) Pemeliharaan menurut ukuran waktu

(a) Pemeliharaan yang dilakukan setiap hari

(b) Pemeliharaan secara berkala atau dalam jangka waktu tertentu

(2) Pemeliharaan menurut ukuran keadaan barang

(a) Pemeliharaan terhadap barang habis pakai

(b) Pemeliharaan tidak habis pakai

5) Inventarisasi dan penghapusan

Salah satu aktivitas dalam administrasi sarana dan prasarana pendidikan adalah inventarisasi sarana dan prasarana yang dimiliki oleh sekolah. Menurut Tatang M. Amirin, dkk (2010: 84), "inventarisasi adalah penyataan dan penyusunan daftar 
barang milik Negara secara sistematik, tertib dan teratur berdasarkan ketentuan-ketentuan pedoman yang berlaku". kegiatan yang dilakukan dalam pelaksanaan inventarisasi adalah :

(a) Mencatat semua barang inventarisasi di dalam "Buku Induk Inventaris" dan buku pembantu "Buku Golongan Inventaris".

(b) Memberikan koding pada barang-barang yang diinventarisasikan

(c) Membuat daftar isian atau format inventaris

(d) Membuat daftar rekapitulasi tahunan

Kegiatan yang terakhir dalam administrasi sarana dan prasarana pendidikan yaitu kegiatan penghapusan sarana dan prasarana pendidikan yang disebabkan oleh sarana dan prasarana yang ada di sekolah sudah tidak memiliki kegunaan lagi atau daya pakainya sudah menurun.

Menurut Ary H. Gunawan (1996: 149), “Penghapusan merupakan proses kegiatan yang bertujuan untuk mengeluarkan atau menghilangkan barang-barang milik negara dari daftar inventaris negara berdasarkan peraturan perundang-undangan yang berlaku".

syarat-syarat penghapusan sarana dan prasarana pendidikan, antara lain:

(a) Dalam keadaan rusak berat yang sudah dipastikan tidak dapat diperbaiki lagi atau dipergunakan lagi.

(b) Pebaikan akan menelan biaya yang sangat besar sekali sehingga merupakan pemborosan uang negara

(c) Secara teknis dan ekonomis kegunaan tidak seimbang dengan biaya pemeliharaan

(d) Penyusutan di luar kekuasaan pengurus barang

(e) Tidak sesuai lagi dengan kebutuhan masa kini

(f) Barang-barang yang jika disimpan lebih lama akan rusak dan tidak dapat dipakai lagi.

(g) Ada penurunan efektivitas kerja 
(h) Dicuri, dibakar, diselewengkan, musnah akibat bencana alam dan sebagainya.

Penghapusan atau penyingkiran sarana dan prasarana pendidikan dapat melalui tahap-tahap berikut ini:

(a) Pemilihan barang yang dilakukan tiap tahun bersamaan dengan waktu memperkirakan waktu kebutuhan

(b) Memperhitungkan faktor-faktor penyingkiran dan penghapusan ditinjau dari segi nilai uang

(c) Membuat perencanaan

(d) Membuat surat pemberitahuan kepada yang akan diadakan penyingkiran dengan menyebutkan barang-barang yang akan disingkirkan

(e) Melaksanakan penyingkiran dengan cara:

(1) Mengadakan lelang

(2) Mengibahkan kepada badan orang lain

(3) Membakar

(4) Penyingkiran disaksikan oleh atasan

(f) Membuat berita acara tentang pelaksanaan penyingkiran. 5). Pengawasan Sarana dan Prasarana Pendidikan Kegiatan pengawasan terhadap sarana dan prasarana pendidikan dilakukan untuk mengontrol sarana dan prasarana pendidikan apakah dalam keadaan baik atau tidak. Agar sarana dan prasarana pendidikan siap pakai sehingga kegiatan belajar mengajar tidak terganggu.

Menurut Prajudi Atmosudirjo (1982), “pengawasan merupakan keseluruhan dari pada kegiatan yang membandingkan atau mengukur apa yang sedang atau sudah dilaksanakan dengan kriteria, norma-norma, standar atau rencana-rencana yang telah ditetapkan sebelumnya".

Menurut Hani Handoko (2003), "pengawasan adalah penetapan standar, pengukuran dan pengambilan tindakan korektif". 
Berdasarkan pendapat di atas, maka dapat disimpulkan bahwa pengawasan merupakan tindakan pengukuran pelaksanaan dan pengambilan keputusan yang sedang atau sudah berjalan untuk mencapai tujuan yang telah ditetapkan

\section{E. Administrasi Keuangan}

Secara terminologis, pengertian administrasi keuangan dibagi menjadi 2 lingkup,yaitu:

- Administrasi keuangan dalam arti sempit yaitu segala pencatatan masuk dan keluarnya keuangan untuk membiayai suatu kegiatan organisasi kerja yang berupa tata usaha atau tata pembukuan keuangan.

- Administrasi keuangan menurut arti luas yaitu kebijakan dalam pengadaan dan penggunaan keuangan untuk mewujudkan kegiatan organisasi kerja yang berupa kegiatan perencanaan, pengaturan pertanggungjawaban, dan pengawasan keuangan.

Dengan demikian, dapat disimpulkan bahwa administrasi keuangan adalah sebagai tata penyelenggaraan keuangan dalam pelaksanaan anggaran belanja negara. Administrasi keuangan meliputi kegiatan perancanaan, penggunaan, pencatatan, laporan, dan pertanggungjawaban dana yang dialokasikan untuk menyelenggarakan pendidikan.

Dalam administrasi keuangan ada pemisahan tugas dan biasanya dikelola oleh bendaharawan yang melakukan pembukuan sesuai dengan aturan yang berlaku. Administrasi keuangan ini ada di tangan urusan administrasi, sedangkan bendaharawan ditunjukan ditunjuk sesuai dengan peraturan yang berlaku.

Tujuan Administrasi Keuangan

Administrasi keuangan bertujuan untuk mewujudkan suatu tertib administrasi keuangan, sehingga pengurusannya dapat dipertanggungjawabkan sesuai dengan ketentuan yang 
berlaku.

Tujuan administrasi keuangan sekolah adalah mewujudkan:

1. Penyelenggaraan pendidikan yang dilaksanakan secara efisien,

2. Terjaminya kelangsungan hidup dan perkembangan sekolah,

3. Tercegahnya kekeliruan, kebocoran atau penyimpangan penggunaan dana,

4. Terjaminnya akuntabilitas perkembangan sekolah

Fungsi Administrasi Keuangan

Fungsi Investasi, meliputi bagaimana pengelolaan dana ke dalam aktiva-aktiva yang akan digunakan untuk berusaha mencapai tujuan tersebut. Dana tersebut bisa berasal dari modal sendiri atau dari luar. Secara garis besar, keputusan investasi dapat dikelompokkan ke dalam 2 macam, yaitu :

1. Investasi jangka pendek meliputi investasi dalam kas, persediaan, piutang, dan lain-lain.

2. Investasi jangka panjang berupa gedung, tanah, peralatan produksi, kendaraan dan lain-lain.

Fungsi Mencari Dana, meliputi fungsi pencarian modal yang dibutuhkan untuk membelanjai usaha-usaha yang dijalankan. Disamping itu, juga berfungsi untuk memilih sumber-sumber dana yang tepat terhadap berbagai jenis kebutuhan. Hal ini berarti bahwa kita berusaha untuk memilih apakah dana itu akan diambil dari pinjaman jangka pendek, pinjaman jangka panjang, atau modal sendiri.

Fungsi Pembelanjaan, meliputi kegiatan tentang penggunaan dana baik dana dari luar maupun dana milik sendiri yang dipergunakan untuk membelanjai seluruh kegiatan. Dalam hal ini pembelanjaan berhubungan dengan proses produksi maupun pendukung proses produksi. 
Fungsi Pembagian Laba, yaitu menentukan policy dalam mengadakan pembagian laba usaha. Fungsi pembagian laba ini sebenarnya dapat dimasukkan di dalam fungsi mencari dana. Maksudnya adalah bahwa diusahakan adanya dana yang berasal dari dalam perusahaan itu sendiri untuk mengembangkan usaha-usaha perusahaan tersebut.

Manfaat Administrasi Keuangan

- Teraturnya penerimaan maupun pengeluaran organisasi.

- Pemanfaatan uang mampu dikendalikan dan dikoordinasikan dengan baik.

- Berkurangnya kekeliruan dalam pembuatan laporan keuangan.

Komponen - Komponen Administrasi Keuangan

1. Perencanaan Keuangan, yaitu merencanakan pemasukan serta pengeluaran keuangan maupun aktivitas-aktivitas lainnya untuk kurun waktu tertentu.

2. Penganggaran Keuangan, yaitu kegiatan-kegiatan organisasi yang meliputi pemasukan, pengeluaran, maupun aktivitas yang telah direncanakan sebelum kemudian dibuat rincian atau detilnya untuk dibuatkan anggarannya.

3. Pengelolaan Keuangan, yaitu suatu kegiatan penggunaan dana sedemikian rupa agar dapat bermanfaat secara maksimal.

4. Pencarian Keuangan, yaitu suatu kegiatan untuk mendapatkan pendanaan agar segala aktivitas organisasi dapat berjalan lancar.

5. Penyimpanan Keuangan, yaitu suatu kegiatan dalam mengumpulkan dana organisasi kemudian menyimpannya dengan aman.

6. Pengendalian Keuangan, yaitu suatu kegiatan yang berkaitan dengan penilaian dan perbaikan sistem maupun kinerja keuangan di dalam organisasi. 
7. Pemeriksaan Keuangan, yaitu suatu kegiatan yang berkaitan dengan pemeriksaan atau audit internal terhadap penggunaan keuangan agar penyimpangan dapat dicegah.Ada beberapa hal yang perlu diperhatikan dalam fungsi pembiayaan, antara lain :

- perencanaan tentang berapa biaya yang diperlukan

o dari mana dan bagaimana biaya itu dapat diperoleh/diusahakan

- bagaimana penggunaanya

- siapa yang akan melaksanakannya

- bagaimana pembukuan dan pertangung jawabannya

o bagaimana pengawasannya,dll.

\section{LATIHAN SOAL}

Kerjakan Soal dibawah ini dengan benar!

1. Jelaskan apa yang dimaksud dengan

a. Administrasi Pendidik dan Tenaga Kependidikan

b. Administrasi Peserta Didik

c. Administrasi Kurikulum

d. Administrasi Sarana dan Prasarana

e. Administrasi Keuangan

2. Buatlah mind mapping indicator dari 5 administrasi diatas! 


\section{BAB III}

Peranan Kepala Sekolah/Madrasah dalam Administrasi

Pendidikan

Kepala sekolah merupakan tugas tambahan dari seorang guru. Tugas tambahan sebagaimana yang dimaksud dalam jabatan tersebut untuk mengendalikan personal yang ada dalam mencapai tujuan yang telah ditetapkan. Dalam perannya tersebut kepala sekolah harus menangani kegiatan rutin, seperti mengendalikan struktur organisasi, melaksanakan administratif, melakukan evaluasi dan pengawasan terhadap kinerja guru. Ketika kepala sekolah mengatur pembelajaran dengan kurikulum sebagai acuannya, maka itu merupakan peran kepala sekolah sebagai administrator yang dituntut untuk mendayagunakan berbagai sumber secara optimal untuk mencapai tujuan pendidikan. Kepala sekolah sebagai administrator modern harus menggunakan prinsip pengembangan dan pendayagunaan organisasi secara kooperatif dan aktifitas-aktifitas yang melibatkan keseluruhan personel dan orang-orang sumber dalam masyarakat.

Peran kepala sekolah sebagai administrator sangat terkait erat dengan proses memanage sumber daya yang ada. Termasuk di dalamnya bagaimana kepala sekolah menjalin hubungan dengan masyarakat luar dalam rangka pengelolaan sekolah secara optimal. Kepala sekolah sebagai administrator harus mampu memberikan bimbingan dan arahan kepada guru perihal kurikulum, masalah kesiswaan, masalah perlengkapan, kepegawaian, serta hubungan sekolah dengan masyarakat. Kualitas sekolah sangat tergantung dari kepala sekolah baik kepala sekolah sebagai administrator maupun kepala sekolah sebagai manajer. Kepala sekolah harus mampu mengelola dan memberdayakan sumber daya yang ada untuk membangun budaya organisasi secara baik. Seluruh aspek pembelajaran hendaknya dapat dikuasai oleh kepala sekolah 
sebagai administrator, yang selanjutnya dapat digunakan untuk melaksanakan pengawasan terhadap kinerja guru.

Memperhatikan teori sebagaimana yang telah diungkapkan tersebut kepala sekolah pada dasarnya diangkat bukan sematamata karena pengalaman masa kerja dan kepangkatannya. Banyak diantara kepala sekolah yang diangkat karena pertimbangan kesenioritasan.

\section{A. Syarat Kepala Sekolah}

Persyaratan menjadi Kepala Sekolah Tahun 2018 berdasarkan Permendikbud Nomor 6 Tahun 2018 Pasal 3 (tiga) sebagai berikut; Dalam hal guru akan di usulkan menjadi bakal calon Kepala Sekolah di daerah khusus, persyaratan sebagaimana dimaksud dalam Pasal 2 ayat(1) huruf $\mathrm{c}$ dan huruf $\mathrm{d}$ dapat dikecualikan dengan ketentuan sebagai berikut:

a. memiliki pangkat paling rendah Penata Muda Tingkat I, golongan ruang III/b; dan

b. memiliki pengalaman mengajar paling sedikit 3 (tiga) tahun.

Guru dapat menjadi bakal calon Kepala Sekolah apabila memenuhi persyaratan sebagai berikut:

- memiliki kualifikasi akademik paling rendah sarjana (S-1) atau diploma empat (D-IV) dari perguruan tinggi dan programs tudi yang terakreditasi paling rendah $\mathrm{B}$;

- memiliki sertifikat pendidik;

- bagi Guru PNS memiliki pangkat paling rendah Penata, golongan ruang III/C;

- pengalaman mengajar paling sedikit 6 (enam) tahun menurut jenis dan jenjang sekolah masing masing, kecuali diTK/TKLB memiliki pengalaman mengajar sekurang-kurangnya 3 (tiga) tahun di TK/TKLB;

- memiliki hasil penilaian prestasi kerja guru dengan sebutan paling rendah "Baik" selama 2 (dua) tahun terakhir; 
- memiliki pengalaman manajerial dengan tugas yang relevan dengan fungsi sekolah paling sedikit 2(dua) tahun;

- sehat jasmani, rohani, dan bebas NAPZA berdasarkan surat keterangan dari rumah sakit Pemerintah;

- tidak pernah di kenakan hukuman di siplin sedang dan/atau berat sesuai dengan ketentuan peraturan perundangundangan;

- tidak sedang menjadi tersangka atau tidak pernah menjadi terpidana; dan

- berusia paling tinggi 56 (lima puluh enam) tahun pada waktu pengangkatan pertama sebagai Kepala Sekolah;

\section{B. Kepemimpinan Kepala sekolah}

Secara etimologi kepala sekolah adalah guru yang memimpin sekolah. Berarti secara terminology kepala sekolah dapat diartikan sebagai tenaga fungsional guru yang diberikan tugas tambahan untuk memimpin suatu sekolah di mana diselenggarakan proses belajar mengajar atau tempat di mana terjadi interaksi antara guru yang memberi pelajaran dan murid yang menerima pelajaran. Kepala Sekolah adalah pimpinan tertinggi di sekolah. Pola kepemimpinananya akan sangat berpengaruh bahkan sangat menentukan kemajuan sekolah. Oleh karena itu dalam pendidikan modern kepemimpinan kepala sekolah merupakan jabatan strategis dalam mencapai tujuan pendidikan.

Menurut Manullang (2006: 55), pemimpin adalah seseorang yang memimpin dengan memprakarsai perilaku sosial dengan mengatur, mengarahkan, mengorganisir bawahan agar menjadi tim kerjasama untuk dapat mencapai tujuan organisasi yang dipimpinnya. Untuk kepentingan tugas pemimpin ini banyak ilmuan cenderung mengemukakan sederet kualitas unggul dan sifat utama yang mesti ada dalam perilaku kepemimpinan. Misalnya memiliki kecerdasan 
tinggi, mampu mengambil kebijaksanaan yang tajam dan akurat, mempunyai rasa humor, mampu memikul tanggung jawab, tepa selira, biasa bertindak adil dan jujur, memiliki keterampilan teknis yang tinggi, dan lain-lain.

Kaitannya dengan peran kepala sekolah sebagai administrator, maka budaya organisasi sebagaimana yang telah diuraikan di atas sangat penting artinya bagi kelangsungan organisasi itu sendiri. Dalam rangka memberdayakan semua personal yang ada kepala sekolah hendaknya menerapkan budaya yang telah dibangun yaitu melibatkan seluruh guru dan staf setiap pengambilan keputusan. Hal ini mengandung makna bahwa semua personal ikut bertanggung jawab dalam menjalankan keputusan yang telah ditetapkan secara bersama-sama.

Kemampuan kepala sekolah dalam mengelola sumberdaya menjadi tolok ukur keberhasilan sekolah. Kemampuan dan keterampilan manajerial kepala sekolah dalam hal ini tidak ada hubungannya dengan tingkat pendidikan. Seorang kepala sekolah harus memiliki keterampilan, dan kaitan dengan perannya sebagai administrator kepala sekolah hendaknya menguasai keterampilan konsep. Made Pidarta (1995) menegaskan "Keterampilan konsep adalah keterampilan untuk menciptakan konsep-konsep baru baik untuk kepentingan manajemen maupun administrasi sekolah". Sebagai seorang administrator kepala sekolah harus mengetahui konsep belajar yang efektif, karena persoalan belajar berhadapan dengan kurikulum, dan implementasi keterampilan konsep ini merupakan bagian dari peran kepala sekolah sebagai administrator. Kaitannya peran kepala sekolah sebagai administrator hendaklah menguasai administrasi kesiswaan, administrasi keuangan, administrasi kepegawaian, dan administrasi human relation. Semua yang disebutkan itu merupakan implementasi kompetensi kepala 
sekolah sebagai seorang administrator. Kompetensi atau kemampuan yang mereka miliki itu diharapkan menguatkan atau melandasi peranan dan tanggung jawabnya sebagai administator, kepala sekolah memerlukan kompetensi administrasi manajemen, kepemimpinan dan supervisi pendidikan.

Aspek kepemimpinan ini dikembangkan secara fleksibel sesuai dengan kondisi dan tuntutan perubahan. Pola kepemimpinan di masa stabil tentu akan berbeda dengan pola kepemimpinan dalam keadaan darurat.

Terdapat tiga teori utama yang merupakan rangkaian ide-ide evolusi pemikiran kepemimpinan yang menyandarkan diri pada metodologi untuk memahami kepemimpinan reduksionis dengan cara mengumpulkan data tentang pemimpin dan situasi, yaitu:

1. Teori Sifat (Trait Theory) yang melihat pada pertanyaan pokok siapakah sosok pemimpin itu? (the leader is). Menurut teori ini keberhasilan suatu organisasi/pemerintahan tergantung pada sifat-sifat dan kualitas pemimpinnya.

2. Teori Perilaku (Behavior Theory) yang memfokuskan perhatiannya pada pertanyaan penting apa yang dilakukan oleh pemimpin itu? (the leader does). Menurut teori ini keberhasilan suatu organisasi/pemerintahan tergantung pada apa yang dapat dilakukan oleh pemimpinnya.

3. Teori Situasional (Situational Theory) yang menaruh perhatiannya pada pertanyaan utama bagaimana situasi pada waktu itu yang dihadapi pemimpin? (in which situation a leader is effective). Menurut teori ini keefektifan upaya dan hasil yang dapat dicapai oleh pemimpin didukung oleh kemampuan pemimpin dalam membaca dengan jeli situasi di tempat kerjanya. 
Diperlukan adanya lembaga pendidikan untuk menghasilkan pimpinan yang tangguh dengan karakter sebagai berikut:

1. Individu-individu suka tantangan, kerja keras, dan berpikir untuk kehidupan bersama yang lebih baik

2. Pemimpin yang cakap dari setiap level dan jenis masyarakat yaitu pemimpin yang dapat membangkitkan spirit dan kesediaan masyarakat untuk bekerja sama yang selama ini bekerja di bawah beban keraguan diri dan kepentingan pribadi.

3. Mempunyai kecakapan dalam bidangnya

4. Menguasai keterampilan-keterampilan: teknis, manusiawi dan konseptual

5. Memiliki visi ke depan, berdisiplin, dan kreatif, karena dunia kita menjadi lebih kompleks dan saling bergantung, perubahan menjadi semakin tidak linier, diskontinu dan tidak dapat diramalkan secara pasti. Masa depan semakin jauh berbeda dengan masa silam, dan semakin jauh berbeda dengan yang kita harapkan.

\section{Tugas dan Tanggung Jawab Kepala Sekolah}

Tugas kepala sekolah dalam bidang administrasi dapat digolongkan menjadi enam bidang yaitu:

a. Pengelolaan pengajaran

Pengelolaan pengajaran ini merupakan dasar kegiatan dalam melaksanakan tugas pokok. Kegiatan yang berhubungan dengan pengelolaan ini antara lain: 
1) Pemimpin pendidikan hendaknya menguasai garis-garis besar program pengajaran untuk tiap bidang studi dan tiap kelas,

2) Menyusun program sekolah untuk satu tahun,

3) Menyusun jadwal pelajaran,

4) Mengkoordinir kegiatan-kegiatan penyusunan model satuan pengajaran,

5) Mengatur kegiatan penilaian,

6) Melaksanakan norma-norma kenaikan kelas,

7) Mencatat dan melaporkan hasil kemampuan belajar murid,

8) Mengkoordinir kegiatan bimbingan sekolah,

9) Mengkoordinir program non kurikuler,

10) Merencanakan pengadaan,

11) Memelihara dan mengembangkan buku perpustakaan sekolah dan alat-alat pelajaran.

b. Pengelolaan kepegawaian

Termasuk dalam bidang ini yaitu menyelenggarakan urusanurusan yang berhubungan dengan penyeleksian, pengangkatan kenaikan pangkat, cuti, perpindahan dan pemberhentian anggota staf sekolah, pembagian tugas-tugas di kalangan anggota staf sekolah, masalah jaminan kesehatan dan ekonomi, penciptaan hubungan kerja yang tepat dan menyenangkan, masalah penerapan kode etik jabatan.

c. Pengelolaan kemuridan

Dalam bidang ini kegiatan yang nampak adalah perencanaan dan penyelenggaran murid baru, pembagian murid atas tingkattingkat, kelas-kelas atau kelompok-kelompok (grouping), perpindahan dan keluar masuknya murid-murid (mutasi), penyelenggaraan pelayanan khusus (special services) bagi murid, mengatur penyelenggaraan dan aktivitas pengajaran, penyelenggaran testing dan kegiatan evaluasi, mempersiapkan 
laporan tentang kemajuan masalah disiplin murid, pengaturan organisasi siswa, masalah absensi, dan sebagainya.

d. Pengelolaan gedung dan halaman

Pengelolaan ini menyangkut usaha-usaha perencanaan dan pengadaan, inventarisasi, pengaturan pemakaian, pemeliharaan, rehabilitasi perlengkapan dan alat-alat material sekolah, keindahan serta kebersihan umum, usaha melengkapi yang berupa antara lain gedung (ruangan sekolah), lapangan tempat bermain, kebun dan halaman sekolah, meubel sekolah, alat-alat pelajaran klasikal dan alat peraga, perpustakaan sekolah, alat-alat permainan dan rekreasi, fasilitas pemeliharaan sekolah, perlengkapan bagi penyelenggaraan khusus, transportasi sekolah, dan alat-alat komunikasi,

e. Pengelolaan keuangan

Dalam bidang ini menyangkut masalah-masalah urusa gaji guruguru dan staf sekolah, urusan penyelenggaraan otorisasi sekolah, urusan uang sekolah dan uang alat-alat murid-murid, usaha-usaha penyediaan biaya bagi penyelenggaraan pertemuan dan perayaan serta keramaian.

f. Pengelolaan hubungan sekolah dan masyarakat Untuk memperoleh simpati dan bantuan dari masyarakat termasuk orang tua murid-murid, dan untuk dapat menciptakan kerjasama antara sekolah-rumah- dan lembaga-lembaga sosial.

2. Tugas Kepala Sekolah Dalam Bidang Supervisi

Supervisi pada dasarnya pelayanan yang disediakan oleh kepala sekolah untuk membantu para guru dan karyawan agar menjadi semakin cakap/terampil dalam melaksanakan tugasnya sesuai dengan tuntutan perkembangan jaman. Supervisi adalah usaha yang dilakukan oleh kepala sekolah dalam membantu guru-guru agar semakin mampu mewujudkan proses belajar mengajar. Di mana Kepala Sekolah bertugas memberikan bimbingan, 
bantuan, pengawasan dan penilaian pada masalah-masalah yang berhubungan dengan teknis penyelenggaraan dan pengembangan pendidikan pengajaran yang berupa perbaikan program dan kegiatan pendidikan pengajaran untuk dapat menciptakan situasi belajar mengajar. Tugas ini antara lain :

a. Membimbing guru-guru agar mereka dapat memahami secara jelas tujuan-tujuan pendidikan pengajaran yang hendak dicapai dan hubungan antara aktivitas pengajaran dengan tujuan-tujuan.

b. Membimbing guru-guru agar mereka dapat memahami lebih jelas tentang persoalan-persoalan dan kebutuhan murid.

c. Menyeleksi dan memberikan tugas-tugas yang paling cocok bagi setiap guru sesuai dengan minat, kemampuan bakat masing-masing dan selanjutnya mendorong mereka untuk terus mengembangkan minat, bakat dan kemampuannya.

d. Memberikan penilaian terhadap prestasi kerja sekolah berdasarkan standar-standar sejauh mana tujuan sekolah itu telah dicapai.

\section{Kompetensi kepala sekolah}

Menurut E. Mulyasa, kepala sekolah mempunyai 7 fungsi utama, yaitu:

1. Kepala Sekolah Sebagai Educator (Pendidik)

Kegiatan belajar mengajar merupakan inti dari proses pendidikan dan guru merupakan pelaksana dan pengembang utama kurikulum di sekolah. Kepala sekolah yang menunjukkan komitmen tinggi dan fokus terhadap pengembangan kurikulum dan kegiatan belajar mengajar di sekolahnya tentu saja akan sangat memperhatikan tingkat kompetensi yang dimiliki gurunya, sekaligus juga akan senantiasa berusaha memfasilitasi dan mendorong agar para guru dapat secara terus menerus meningkatkan kompetensinya, 
sehingga kegiatan belajar mengajar dapat berjalan efektif dan efisien.

2. Kepala Sekolah Sebagai Manajer

Dalam mengelola tenaga kependidikan, salah satu tugas yang harus dilakukan kepala sekolah adalah melaksanakan kegiatan pemeliharaan dan pengembangan profesi para guru. Dalam hal ini, kepala sekolah seyogyanya dapat memfasiltasi dan memberikan kesempatan yang luas kepada para guru untuk dapat melaksanakan kegiatan pengembangan profesi melalui berbagai kegiatan pendidikan dan pelatihan, baik yang dilaksanakan di sekolah, seperti: MGMP/MGP tingkat sekolah, atau melalui kegiatan pendidikan dan pelatihan di luar sekolah, seperti kesempatan melanjutkan pendidikan atau mengikuti berbagai kegiatan pelatihan yang diselenggarakan pihak lain.

3. Kepala Sekolah Sebagai Administrator

Khususnya berkenaan dengan pengelolaan keuangan, bahwa untuk tercapainya peningkatan kompetensi guru tidak lepas dari faktor biaya. Seberapa besar sekolah dapat mengalokasikan anggaran peningkatan kompetensi guru tentunya akan mempengaruhi terhadap tingkat kompetensi para gurunya. Oleh karena itu kepala sekolah seyogyanya dapat mengalokasikan anggaran yang memadai bagi upaya peningkatan kompetensi guru.

\section{Kepala Sekolah Sebagai Supervisor}

Untuk mengetahui sejauh mana guru mampu melaksanakan pembelajaran, secara berkala kepala sekolah perlu melaksanakan kegiatan supervisi, yang dapat dilakukan melalui kegiatan kunjungan kelas untuk mengamati proses pembelajaran secara langsung, terutama dalam pemilihan dan penggunaan metode, media yang digunakan dan keterlibatan siswa dalam proses pembelajaran. Dari hasil supervisi ini, dapat diketahui kelemahan sekaligus keunggulan guru dalam melaksanakan pembelajaran, tingkat penguasaan kompetensi guru yang bersangkutan, 
selanjutnya diupayakan solusi, pembinaan dan tindak lanjut tertentu sehingga guru dapat memperbaiki kekurangan yang ada sekaligus mempertahankan keunggulannya dalam melaksanakan pembelajaran. Sebagaimana disampaikan oleh Sudarwan Danim mengemukakan bahwa menghadapi kurikulum yang berisi perubahan-perubahan yang cukup besar dalam tujuan, isi, metode dan evaluasi pengajarannya, sudah sewajarnya kalau para guru mengharapkan saran dan bimbingan dari kepala sekolah mereka. Dari ungkapan ini, mengandung makna bahwa kepala sekolah harus betul-betul menguasai tentang kurikulum sekolah. Mustahil seorang kepala sekolah dapat memberikan saran dan bimbingan kepada guru, sementara dia sendiri tidak menguasainya dengan baik.

\section{Kepala Sekolah Sebagai Leader (Pemimpin)}

Gaya kepemimpinan kepala sekolah seperti apakah yang dapat menumbuh-suburkan kreativitas sekaligus dapat mendorong terhadap peningkatan kompetensi guru? Dalam teori kepemimpinan setidaknya kita mengenal dua gaya kepemimpinan yaitu kepemimpinan yang berorientasi pada tugas dan kepemimpinan yang berorientasi pada manusia. Dalam rangka meningkatkan kompetensi guru, seorang kepala sekolah dapat menerapkan kedua gaya kepemimpinan tersebut secara tepat dan fleksibel, disesuaikan dengan kondisi dan kebutuhan yang ada. Mulyasa menyebutkan kepemimpinan seseorang sangat berkaitan dengan kepribadian, dan kepribadian kepala sekolah sebagai pemimpin akan tercermin sifat-sifat sebagai barikut : (1) jujur; (2) percaya diri; (3) tanggung jawab; (4) berani mengambil resiko dan keputusan; (5) berjiwa besar; (6) emosi yang stabil, dan (7) teladan. 6. Kepala Sekolah Sebagai Inovator

Dalam rangka melakukan peran dan fungsinya sebagai innovator, kepala sekolah harus memiliki strategi yang tepat untuk menjalin hubungan yang harmonis dengan lingkungan, mencari gagasan 
baru, mengintegrasikan setiap kegiatan, memberikan teladan kepada seluruh tenaga kependidikan sekolah, dan mengembangkan model model pembelajaran yang inofatif. Kepala sekolah sebagai inovator akan tercermin dari cara cara ia melakukan pekerjaannya secara konstruktif, kreatif, delegatif, integratif, rasional, objektif, pragmatis, keteladanan

7. Kepala Sekolah Sebagai Motivator

Sebagai motivator, kepala sekolah harus memiliki strategi yang tepat untuk memberikan motivasi tenaga kependidikan dalam melaksanakan tugas dan fungsinya.Motivasi ini dapat ditumbuhkan melalui pengaturan lingkungan fisik, pengaturan suasana kerja, disiplin, dorongan, penghargaan secara efektif, dan penyediaan berbagai sumber belajar melalui pengembangan Pusat Sumber Belajar (PSB)

Kompetensi yang harus dimiliki oleh Kepala Sekolah / Madrasah berdasarkan Peraturan Menteri Pendidikan Nasional Nomor 13 Tahun 2007 tentang Standar Kepala Sekolah/Madrasah terdiri dari 5 kompetensi di antaranya : kompetensi manajerial, kompetensi kewirausahaan, kompetensi supervisi, kompetensi kepribadian, dan kompetensi sosial.

Berikut unsur-unsur selengkapnya tentang 5 kompetensi yang harus dimiliki oleh kepala sekolah ataupun kepala madrasah :

\section{Kompetensi Manajerial}

a. Menyusun perencanaan sekolah/madrasah untuk berbagai tingkatan perencanaan.

b. Mengembangkan organisasi sekolah/madrasah sesuai dengan kebutuhan.

c. Memimpin sekolah/madrasah dalam rangka pendayagunaan sumber daya sekolah/madrasah secara optimal.

d. Mengelola perubahan dan pengembangan sekolah/madrasah menuju organisasi pembelajar yang efektif. 
e. Menciptakan budaya dan iklim sekolah/madrasah yang kondusif dan inovatif bagi pembelajaran peserta didik.

f. Mengelola guru dan staf dalam rangka pendayagunaan sumber daya manusia secara optimal.

g. Mengelola sarana dan prasarana sekolah/madrasah dalam rangka pendayagunaan secara optimal.

h. Mengelola hubungan sekolah/madrasah dan masyarakat dalam rangka pencarian dukungan ide, sumber belajar, dan pembiayaan sekolah/madrasah.

i. Mengelola peserta didik dalam rangka penerimaan peserta didik baru, dan penempatan dan pengembangan kapasitas peserta didik.

j. Mengelola pengembangan kurikulum dan kegiatan pembelajaran sesuai dengan arah dan tujuan pendidikan nasional.

k. Mengelola keuangan sekolah/madrasah sesuai dengan prinsip pengelolaan yang akuntabel, transparan, dan efisien.

I. Mengelola ketatausahaan sekolah/madrasah dalam mendukung pencapaian tujuan sekolah/ madrasah.

m. Mengelola unit layanan khusus sekolah/madrasah dalam mendukung kegiatan pembelajaran dan kegiatan peserta didik di ekolah/madrasah.

n. Mengelola sistem informasi sekolah/madrasah dalam mendukung penyusunan program dan pengambilan keputusan.

o. Memanfaatkan kemajuan teknologi informasi bagi peningkatan pembelajaran dan manajemen sekolah/madrasah.

p. Melakukan monitoring, evaluasi, dan pelaporan pelaksanaan program kegiatan sekolah/madrasah dengan prosedur yang tepat, serta merencanakan tindak lanjutnya.

\section{Kompetensi Kewirausahaan}

a. Menciptakan inovasi yang berguna bagi pengembangan sekolah/madrasah.

b. Bekerja keras untuk mencapai keberhasilan sekolah/madrasah sebagai organisasi pembelajar yang efektif. 
c. Memiliki motivasi yang kuat untuk sukses dalam melaksanakan tugas pokok dan fungsinya sebagai pemimpin sekolah/madrasah.

d. Pantang menyerah dan selalu mencari solusi terbaik dalam menghadapi kendala yang dihadapi sekolah/madrasah.

e. Memiliki naluri kewirausahaan dalam mengelola kegiatan produksi/jasa sekolah/madrasah sebagai sumber belajar peserta didik.

\section{Kompetensi Supervisi}

a. Merencanakan program supervisi akademik dalam rangka peningkatan profesionalisme guru.

b. Melaksanakan supervisi akademik terhadap guru dengan menggunakan pendekatan dan teknik supervisi yang tepat.

c. Menindaklanjuti hasil supervisi akademik terhadap guru dalam rangka peningkatan profesionalisme guru.

\section{Kompetensi Kepribadian}

a. Berakhlak mulia, mengembangkan budaya dan tradisi akhlak mulia, dan menjadi teladan akhlak mulia bagi komunitas di sekolah/madrasah.

b. Memiliki integritas kepribadian sebagai pemimpin.

c. Memiliki keinginan yang kuat dalam pengembangan diri sebagai kepala sekolah/madrasah.

d. Bersikap terbuka dalam melaksanakan tugas pokok dan fungsi.

e. Mengendalikan diri dalam menghadapi masalah dalam pekerjaan sebagai kepala sekolah/madrasah.

f. Memiliki bakat dan minat jabatan sebagai pemimpin pendidikan.

\section{Kompetensi Sosial}

a. Bekerja sama dengan pihak lain untuk kepentingan sekolah/madrasah

b. Berpartisipasi dalam kegiatan sosial kemasyarakatan. 


\section{c. Memiliki kepekaan sosial terhadap orang atau kelompok lain \\ E. Prinsip-prinsip Kepemimpinan Kepala Sekolah}

Prinsip adalah suatu pernyataan fundamental atau kebenaran umum maupun individual yang dijadikan oleh seseorang/kelompok sebagai pedoman untuk bertindak

Prinsip kapasitas integratif adalah prinsip yang sangat penting bagi seorang pemimpin, karena hanya dengan kapasitas yang demikianlah administrasi dan organisasi dapat digerakkan sebagai suatu total sistem ke arah pencapaian tujuan yang telah ditentukan. Pemimpin dengan integritas tinggi adalah sama di dalam dan di luar batinnya, dalam makna apa yang ada di dalam diri maupun penampakan di permukaan.

Peranan pemimpin inilah yang akan menggerakkan organisasi, antara lain:

1. Membantu menciptakan iklim sosial yang baik.

2. Membantu kelompok untuk mengorganisasikan diri.

3. Membantu kelompok dalam menetapkan prosedur kerja.

4. Mengambil tanggungjawab untuk menetapkan keputusan bersama dengan kelompok.

5. Memberi kesempatan pada kelompok untuk belajar dari pengalaman.

Dalam organisasi pendidikan antara lain adalah sekolah, secara formal

Kepala sekolah adalah pemimpin secara keseluruhan, Sehingga Kepala sekolah harus memahami fungsi kedudukan, diantaranya:

1. Membawa perubahan yang signifikan.

2. Menciptakan visi dan menuangkan misi dalam kenyataan.

3. Menetapkan kebijakan dan tujuan yang hendak dicapai

4. Mempengaruhi, mendorong, mengajak, menuntun dan menggerakkan seluruh 
anggota (sumber daya) untuk mencapai tujuan yang telah disepakati bersama. Antara kepemimpinan dan manajerial tidak dapat dipisahkan. Pemimpin

dalam mengelola sekolah adalah mengatur agar seluruh potensi sekolah berfungsi secara optimal dalam mendukung tercapainya tujuan sekolah. Kepala sekolah mempunyai tugas merencanakan, mengorganisasikan, mengawasi, dan mengevaluasi, seluruh kegiatan pendidikan di sekolah

Dengan demikian pemimpin harus memiliki kepercayaan dari pengikutnya oleh karenanya harus menampilkan integritas. Jujur transaksi, diprediksi reaksi, emosi terkontrol dengan baik, tidak mudah marah. Selain itu pemimpin dengan integritas tinggi akan lebih mudah didekati oleh pengikutnya.

Prinsip-prinsip kepemimpinan sebagai berikut:

\section{Kooperatif}

Yaitu dalam proses kepemimpinannya kepala sekolah hendaknya mementingkan kerjasama dengan orang-orang yang dipimpinnya, karena dalam prinsip kooperatif ini partisipasi harus ditingkatkan menjadi kerjasama yang dinamis.

Dalam kepemimpinan kooperatif memungkinkan pekerjaan merupakan tanggungjawab bersama dan adanya kerjasama yang baik antara subsistem yang ada di dalam organisasi dalam mencapai tujuan yang telah ditentukan. Namun kepemimpinan kooperatif harus menyadari tidak semua pegawai mampu menjalin kerjasama, baik dengan sesama rekan kerja maupun dengan atasannya. Dalam kaitannya dengan ini terkadang terjadi kesenjangan antara bawahan dengan sesama bawahan maupun antara bawahan dengan atasan. Untuk itu dibutuhkan prinsipprinsip yang lain untuk mengatasi hal tersebut.

\section{Rasionalitas dan Obyektivitas}


Yaitu sebagai pemimpin tidak akan berhasil apabila menggerakkan organisasinya dengan cara emosional. Artinya jika emosi merajai cara berpikir seorang pemimpin, maka rasionalitas dan obyektivitas akan berkurang dan yang pada gilirannya keputusan yang dibuat tidak akan tepat. Kepemimpinan rasional ini ditandai dengan penampilan seorang tokoh yang didasarkan pada kemampuan dan kecakapan yang dimilikinya, semakin tinggi kedudukan manajerial seseorang semakin besar pula tuntutan kepadanya untuk membuktikan kemampuannya untuk berpikir. Hasil pemikiran itu akan terasa dampaknya tidak hanya dalam organisasi, akan tetapi juga dalam hubungan organisasi dengan pihak-pihak yang berkepentingan di luar organisasi tersebut.

Dalam memandang atau memutuskan suatu masalah seorang pemimpin harus terbuka, artinya memandang dari segala sisi dan kronologinya. Keterbukaan berarti mampu mendengarkan ide-ide baru, bahkan mungkin tidak sesuai dengan cara berpikir biasa. Keterbukaan dalam kepemimpinan akan membangun saling menghormati antara pemimpin dan pengikut serta membuat tim secara baik dengan gagasan-gagasan baru untuk mewujudkan visinya.

\section{Adaptabilitas dan Fleksibilitas}

Yaitu jika ada pendapat yang mengatakan bahwa satu-satunya hal yang konstan di dunia ini adalah perubahan, maka sikap kaku dan apriori akan merugikan seseorang dalam menjalankan peranannya selaku pemimpin. Maka dari kefleksibelan suatu organisasi akan menjamin hubungan kerja dan tata kerja yang sesuai denagn kenyataan dan masalah baru yang muncul dan selalu berubah. Perubahan tersebut tidak bisa terlepas dari berbagai hubungan kemanusiaan diantara anggota staf. Dengan demikian prinsip fleksibilitas merupakan faktor yang sangat penting dalam suatu organisasi. 
Adaptif berarti cerdas menyesuaikan diri dengan perubahan. Kepemimpinan adaptif berarti kepemimpinan yang mudah menyesuaikan dirinya dengan perubahan dan keadaan baru. Perubahan selalu membentuk pandangan baru, dan pandangan baru akan mempengaruhi berbagai peristiwa yang sedang berjalan

\section{Delegasi}

Yaitu sebagai pemimpin pendidikan kepala sekolah harus menyadari bahwa kemampuannya sebagai manusia adalah terbatas, sehingga perlu mendelegasikan kekuasan, wewenang dan tanggung jawabnya kepada anggoga stafnya menurut kemampuan masing-masing, supaya proses kerja tersebut secara keseluruhan dapat berjalan lancar, efektif dan efisien. Pembinaan kepemimpinan melalui latihan dalam bentuk pendelegasian merupakan salah satu cara yang cukup praktis bagi kepentingan peningkatan mutu pendidikan di masa yang akan datang. Ini berarti bahwa sebernanya keberhasilan dalam memimpin itu tergantung pada kemampuan dalam mendelegasikan tugas dan tanggung jawab kepada bawahan secara efektif. Seorang pemimpin harus bisa memilah-milah tugas pokok organisasinya dan mengevaluasi yang dapat dan tidak dapat dilimpahkan pada orang-orang yang dipercayainya. Pemimpin harus bersedia dan mempercayai orangorang lain sesuai posisi/jabatannya. Sedang penerima delegasi harus mampu memlihara kepercayaan itu, dengan melaksanakannya dengan penuh tanggung jawab. Pendelegasian ini harus diwujudkan karena karena kemajuan kelompok/ organisasinya yang tidak mungkin diwujudkan sendiri. Sehubungan dengan itu musyawarah dan konsultasi ikut berperan, terutama bagi penerima

Partisipasi dalam kepemimpinan hanya mungkin terwujud jika pemimpin mengembangkan komunikasi yang memumngkinkan terjadinya pertukaran pendapat, gagasan dan pandangan dalam memecahkan masalah-masalah, yang bagi pemimpin akan dapat 
dimanfaatkan untuk mengambil keputusan-keputusan.

Seorang pemimpin harus bisa memberikan kepercayaan kepada koleganya dalam menjalankan tugas yang diembannya untuk melakukan aktivitas seluas-luasnya. Namun semua dalam pelaksanaannya harus terukur dan harus bisa dipertanggungjawabkan secara moral dan konstitusional.

\section{Pragmatisme}

Yaitu pemimpin pendidikan harus dapat membuat keputusan yang akurat sesuai dengan kemampuan dan sumber-sumber yang tersedia. Ini merupakan salah satu ciri pemimpin yang baik.

Kepemimpinan pragmatis adalah konsep kepemimpinan yang dibutuhkan untuk membuat keputusan yang tepat waktu, cepat, efektif, tapi tidak melanggar prinsip. Pragmatisme berarti konsentrasi pada fakta bukan emosi atau cita-cita. Hal ini berarti, pemimpin harus bersikap realistis dengan rencana, dan mau bertindak langkah demi langkah, untuk melakukan tindakan produktif dari situasi yang nyata.

Yaitu dalam memimpin lembaga pendidikan, permimpin pendidikan harus dapat menjadi contoh yang baik. Pemimpin tidak hanya bisa memerintah dan menilai kinerja bawahannya tetapi harus memberi contoh bekerja yang baik. Seorang pemimpin dalam menghabiskan waktu atau energi apa saja yang diperlukan untuk menyelesaikan tugas yang menjadi tanggung jawabnya. Pemimpin hatus mengilhami dedikasi dengan memberi contoh, melakukan apapun untuk menyelesaikan tugas dan tanggung jawabnya menuju visi

Dalam Permendiknas nomor 13 tahun 2007 tentang Standar Kepala Sekolah/Madrasah yang menyebutkan tentang kualifikasi seseorang menjadi kepala sekolah/madrasah baik secara umum maupun khusus. Disebutkan juga bahwa kepala sekolah/madrasah harus mempunyai kompetensi yang harus dipenuhi, yaitu: 
1. Kepribadian, yaitu: berakhlak mulia, memiliki integritas, bersikap terbuka, memiliki bakat dan minat sebagai pemimpin.

2. Manajerial, yaitu: menyusun perencanaan, mengembangkan dan memimpin sekolah/madrasah, mengelola keuangan, unit layanan, memanfaatkan kemajuan teknologi, dan melakukan monitoring.

3. Kewirausahaan, yaitu; menciptakan inovasi bagi pengembangan sekolah/madrasah, bekerja keras, pantang menyerah, memililki naluri kewirausahaan.

4. Supervisi, yaitu: merencanakan program dan melaksanakan supervise serta menindaklanjuti supervise pendidikan.

5. Sosial, yaitu: bekerja sama dengan pihak lain, berpartisipasi kegiatan sosial,dan memiliki kepekaan terhadap orang lain.

\section{F. Visionary leadership Kepala Sekolah/Madrasah}

Terdapat beberapa teori yang melandasinya, yaitu:

1. The Great Man Theory. Menurut teori ini orang bisa berhasil menjadi pemimpin yang baik, karena memang dilahirkan demikian. Sebab kemunculan The Great man theory: Anggapan / keyakinan sebagian masyarakat dan sebagai konsekwensi dari anggapan studi awal tentang kepribadian yang diyakini sifatnya bawaan.

2. Teori Darwinisme Sosial yang dikembangkan dari Teori Evolusinya Charles Darwin: Strugle for life - Survival of the fittes.

3. Teori Kekacauan (chaos theory) menurut Michael Crichton mengajarkan kebenaran dari hal yang sebaliknya. Bahwa ajaran liniaritas yang bersifat lurus ke depan, sama sekali tidak ada. Liniaritas adalah cara pandang yang keliru terhadap dunia. Kehidupan nyata bukan merupakan rangkaian peristiwa yang saling terkait yang terjadi secara susul-menyusul seperti manik-manik yang direnteng menjadi 
sebuah kalung. Gelombang perubahan hidup bergeser dari pola kehidupan yang seimbang (equilibrium) ke pola linearitas di mana semua bergerak lurus ke depan. Kemudian berubah pula memasuki masa chaos, di mana kehidupan tidak lagi lurus ke depan, tapi adakalanya bergerak tak beraturan, ada kalanya bergerak ke depan, sesekali ke belakang, pada sisi lain bergerak ke samping, namun bisa saja melakukan loncatan jauh ke depan. Dari gelombang chaos (kekacauan), dunia akan kembali ke pola kehidupan yang seimbang (equilibrium).

d. Murray yang dikutip oleh Hall dan Lindzey, menyatakan bahwa kepribadian manusia merupakan kompromi antara impuls-impuls individu sendiri dan tuntutan-tuntutan serta kepentingan-kepentingan orang-orang lain. Tuntutan dari orang-orang lain ini diwakili secara kolektif oleh pranatapranata dan pola-pola budaya tempat individu itu berada, sedangkan proses yang mana impuls-impulsnya sendiri dikompromikan oleh kekuatan-kekuatan ini disebut proses sosialisasi. Konflik-konflik antara individu dan pola-pola lingkungan sosial yang berlaku, biasanya dipecahkan dengan cara individu menyesuaikan diri dengan pola-pola kelompok dengan cara tertentu. Hanya kadang- kadang dan pada kasus individu-individu luar biasa, orang bisa mengadakan perubahan pola-pola budaya yang akan mengurangi konfliknya dengan impuls-impulsnya sendiri. Dalam sejarah Is- lam, pola dan kepemimpinan yang ditampilkan Rasulullah Muhammad Saw. mampu merubah habitus masyarakatnya dari tatanan sosial masyarakat jahiliyyah menjadi masyarakat madaniyyah (berperadaban tinggi) menunjukkan keunggulan kualitas kepribadiannya sebagai seorang pemimpin besar. 4 sifat utama yang dimiliki Rasulullah Muhammad Saw.: Tabligh (menyampaikan), Amanah (terpercaya), Fathonah (cerdas), dan Shiddiq (benar). 
e. Teori Ekologi. Penganut teori ini berpendapat bahwa seorang pemimpin lahir karena ia memiliki bakat-bakat sebagai seorang pemimpin dan bakat tersebut dikembangkan melalui pendidikan dan pelatihan (training) serta diberikan kesempatan untuk melaksanakan kepemimpinannya.

f. Menurut Perls, seseorang yang membebaskan diri dari bantuan lingkungan dalam hal fisik sesuatu yang biasa terjadi dan tidak sulit. Akan tetapi seseorang yang berusaha membebaskan diri dari bantuan lingkungan dalam hal psikologis dan sosial menimbulkan masalah-masalah yang besar dan menyebabkan "konflik dasar" (basic conflict) dalam kehidupan manusia. Konflik ini terjadi antara siapa kita dan apa yang diinginkan orang-orang lain terhadap kita untuk menjadi. Konflik timbul karena seseorang hidup dalam suatu masyarakat yang mengharapkan orang tersebut menjadi sesuatu yang lain dari dirinya sendiri.

Karakter pemimpin yang besar:

1. Memiliki keyakinan diri yang kuat

2. Menghadirkan diri di saat-saat sulit

3. Memegang teguh nilai-nilai

4. Mempunyai komitmen tinggi

5. Menumbuhkan rasa bangga terhadap pengikutnya,

6. Memiliki visi yang jelas, tujuan yang pasti dan tekun.

Proses kepemimpinan merupakan seni yang bukan hanya bersifat teoritis, tetapi juga praktis. Pada tataran praktisnya, banyak hal-hal yang tak terduga dan amat menegangkan baik secara psikis maupun fisik, sehingga tidak akan sanggup dihadapi oleh orangorang biasa (normal) yang merupakan bagian kebanyakan dari individu-individu dalam suatu masyarakat.

Diperlukan adanya lembaga pendidikan untuk menghasilkan pimpinan yang tangguh dengan karakter sebagai berikut:

1. Individu-individu suka tantangan, kerja keras, dan berpikir untuk kehidupan bersama yang lebih baik 
2. Pemimpin yang cakap dari setiap level dan jenis masyarakat yaitu pemimpin yang dapat membangkitkan spirit dan kesediaan masyarakat untuk bekerja sama yang selama ini bekerja di bawah beban keraguan diri dan kepentingan pribadi.

3. Mempunyai kecakapan dalam bidangnya

4. Menguasai keterampilan-keterampilan: teknis, manusiawi dan konseptual

5. Memiliki visi ke depan, berdisiplin, dan kreatif, karena dunia kita menjadi lebih kompleks dan saling bergantung, perubahan menjadi semakin tidak linier, diskontinu dan tidak dapat diramalkan secara pasti. Masa depan semakin jauh berbeda dengan masa silam, dan semakin jauh berbeda dengan yang kita harapkan.

\section{LATIHAN SOAL}

Kerjakan soal-soal dibawah ini

1. Siapa yang dimaksud dengan kepala sekolah dan sebutkan syarat-syarat menjadi kepala sekolah ?

2. Apa yang dimaksud dengan kepemimpinan?

3. Jelaskan tugas tanggung jawab kepala sekolah!

4. Jelaskan kompetensi yang wajib dimiliki kepala sekolah dalam meningkatkan mutu sekolah!

5. Sebutkan prinsip-prinsip kepala sekolah! 


\section{BAB IV \\ Supervisi Pendidikan}

\section{A. Supervisi Pendidikan}

Supervisi merupakan salah satu fungsi kepala sekolah untuk meningkatkan kualitas dan profesionalisme guru dalam melaksanakan pengajaran. Sehubungan dengan pentingnya aktifitas supervisi sekolah yang berkaitan dengan peningkatan kualitas guru pada khususnya dan peningkatan mutu pendidikan pada umumnya.

Terdapat beberapa pengertian mengenai supervisi. Menurut Good Carter ( dalam Sahertian, 2008) ,supervisi adalah usaha dari petugas- petugas sekolah dalam memimpin guru- guru dan petugas- petugas lainnya dalam memperbaiki pengajaran, termasuk menstimulasi, merevisi tujuan- tujuan pendidikan, bahan pengajaran, metode, dan evaluasi pengajaran.

Mc Nerney (dalam Sahertian, 2008) menyatakan bahwa supervisi adalah suatu prosedur, memberi arah dan mengadakan penilaian secara kritis terhadap proses pengajaran.

Menurut Kimball Wiles (dalam Sahertian, 2008), supervisi adalah bantuan yang diberikan untuk memperbaiki situasi belajar mengajar agar dapat menjadi lebih baik. Seorang supervisor yang baik sebaiknya memiliki lima ketrampilan, yaitu: Ketrampilan dalam hubungan- hubungan kemanusiaan, Ketrampilan dalam proses kelompok, Ketrampilan dalam kepemimpinan pendidikan, Ketrampilan dalam mengatur tenaga kependidikan, Ketrampilan dalam evaluasi.

Menurut Suhardan (2010) Supervisi merupakan pengawasan terhadap pelaksanaan kegiatan teknis edukatif di sekolah, bukan 
sekedar pengawasan terhadap fisik material. Supervisi merupakan pengawasan terhadap kegiatan akademik yang berupa proses belajar mengajar, pengawasan terhadap guru dalam mengajar, pengawasan terhadap murid yang belajar dan pengawasan terhadap situasi yang menyebabkannya.

Menurut Sahertian (2010) supervisi adalah usaha memberikan layanan kepada guru-guru baik secara individu maupun secara berkelompok dalam usaha memperbaiki pengajaran. Kata kunci dari pemberian supervisi pada akhirnya ialah memberikan layanan dan bantuan.

Suharsimi Arikunto dalam bukunya yang berjudul Dasar - Dasar Supervisi (2006) , ditinjau dari kegiatan supervisi , maka supervisi dapat dibedakan menjadi dua, yakni :

1. Supervisi akademik adalah supervisi yang obyeknya menitik beratkan pengamatan pada masalah akademik, yaitu yang langsung berada dalam lingkup kegiatan pembelajaran yang dilakukan oleh dosen untuk membantu mahasiswa ketika “ sedang dalam proses belajar atau mempelajari sesuatu “. Disebut supervisi akademik karena obyek utamanya adalah aspek- aspek akademik. Supervisi akademik dapat dilakukan oleh intern lembaga sendiri yaitu oleh teman sejawat, ketua program studi atau Pembantu Rektor I bidang akademis.

2. Supervisi administrasi adalah supervisi yang obyeknya menitik beratkan pengamatan pada aspek- aspek administrasi yang berfungsi sebagai pendukung dan memperlancar terlaksananya proses pembelajaran, dapat berupa kurikulum sekolah, penentuan dosen pengampu mata kuliah, penyusunan jadwal kuliah, laporan nilai mahasiswa, presensi kehadiran dosen dan mahasiswa, rasio dosen dan mahasiswa, tingkat pendidikan dosen dan tenaga kependidikan, prestasi yang diperoleh mahasiswa dsb. Supervisi administrasi dapat dilakukan oleh internal lembaga. 
3. Kegiatan supervisi yang tanpa menunjuk pada obyek ( lingkup nomor (1) dan (2), yaitu pembelajaran serta semua faktor pendukungnya, seluruhnya itulah yang disebut sebagai supervisi pendidikan, sedang apabila menentukan obyeknya maka dikatakan sebagai supervisi pengajaran (Arikunto, 2006: 5).

\section{B. Tujuan Supervisi Pendidikan}

Tujuan utama kegiatan supervisi menurut Arikunto (2006) adalah meningkatkan kualitas pembelajaran, yang harapan akhirnya pada prestasi belajar siswa. Tentu saja peningkatan tersebut tidak hanya mengenai satu aspek saja, akan tetapi semua unsur yang terkait dalam proses pembelajaran diantaranya siswa itu sendiri, guru dan personil lain, peralatan, pengelolaan maupun lingkungan tempat belajar.

Menurut Sahertian (2010) tujuan supervisi adalah memberikan layanan dan bantuan untuk mengembangkan situasi belajarmengajar yang dilakukan guru dalam kelas. Dengan demikian jelas bahwa tujuan supervisi adalah memberikan layanan dan bantuan untuk meningkatkan kualitas mengajar guru di kelas yang pada gilirannya untuk meningkatkan kualitas belajar siswa. Bukan hanya memperbaiki kemampuan mengajar tapi juga untuk pengembangan potensi kualitas guru.

Pidarta (2009) ada sejumalah tujuan supervisi pendidikan seperti membantu guru mengembangkan profesi, pribadi, sosialnya, membantu kepala sekolah menyesuaikan program pendidikan dengan kondisi masyarakat setempat dan ikut berjuang meningkatkan kualitas dan kuantitas lulusan.

Berdasarkan teori diatas maka dapat disimpulkan tujuan dari supervisi pendidikan adalah usaha untuk meningkatkan kualitas pembelajaran dengan cara memberikan layanan dan bantuan untuk meningkatkan kualitas mengajar guru di kelas sehingga 
membantu guru mengembangkan profesi, pribadi dan membantu kepala sekolah menyesuaikan program pendidikan yang sesuai dengan kondisi masyarakat.

\section{Prinsip Supervisi Pendidikan}

Menurut Arikunto (2006:19) prinsip-prinsip supervisi antara lain:

1. Supervisi bersifat memberikan bimbingan dan memberi bantuan kepada guru dan staf sekolah lain untuk mengatasi masalah danmengatasi kesulitan dan bukan untuk mencaricari kesalahan. Dengan demikian maka dalam melakukan supervisi, pengwas dan kepala sekolah haru menitikberatkan pada segala langkah yang diambil oleh sekolah termasuk bagaimana upaya yang telah diambil apabila mengalami kesulitan.

2. Pemberian bantuan dan bimbingan secara lengsung, maksudnya

bimbingan dan bantuan tidak diberikan secara langsung tetapi harus diupayakan agar pihak yang bersangkutan tanpa dipaksa atau dibukakan hatinya dapat mersa sendiri serta sepada dengan kemampuan untuk dapat mengatasi sendiri.

3. Apabila supervisor merencanakan akan memberikan umpan balik, sebaiknya disampaikan sesegera mungkin agar tidak lupa.

4. Kegiatan supervisi dilakukan secara berkala misalnnya 3 bulan sekali.

5. Suasana yang terjadi selama supervisi berlangsung hendaknya mencerminkan adanya hubungan yang baik antara supervisor dan yang disupervisi.

6. Untuk menjaga agar apa yang dilakukan dan ditemukan tidak hilang dan terlupakan, sebaiknya supervisor 
membuat catatan singkat, berisikan hal-hal penting yang diperlukan untuk membuat laporan.

Sedangkan menurut Purwanto dalam Arikunto (2006) prinsipprinsip yang perlu diperhatikan dalam supervisi adalah:

1. Supervisi hendaknya bersifat konstruktif dan kreatif, yaitu bahwa dari para supervisor seyogyanya dapat memberikan motivasi kepada pihak-pihak yang disupervisi sehingga tumbuh dorongan atau motivasi untuk bekerja lebih giat dan mencapai hasil yang lebih baik.

2. Supervisi hendaknya didasarkan pada keadaan dan kenyataan yang sesuai dengan sebenar-benarnya terjadi sehingga kegiatan supervisi dapat terlaksana dengan realistis dan mudah dilaksanakan.

3. Kegiatan supervisi hendaknya terlaksana dengan sederhana, tidak terlalu kaku dan muluk tetapi sewajarnya.

4. Supervisi hendaknya dapat memberikan rasa aman kepada yang pihak yang disupervisi, bukan sebaliknya menimbulkan rasa tercekam, takut, was-was dan sebagainya.

5. Dalam pelaksanaan supervisi hendaknya terjalin hubungan profesional antara pihan mensupervi dan pihak yang disupervisi, bukan didasarkan hubungan pribadi.

6. Supervisi hendaknya didasarkan pada jenis kemempuan, kesanggupan, kondisi dan sikap yang disupervisi agar tidak menimbulkan rasa strss pada pihak yang disupervisi.

7. Supervisi tidak dilaksanakan dalam situasi mendesak sehingga berdampak pada rasa gelisah yang selanjutnya mungkin menumbuhkan sikap jengkel apalagi berdampak antipati dari pihak yang disupervisi.

8. Supervisi bukanlah inspeksi sehingga tidaklah tepat jika supervisor bertindak mencari-cari kesalahan dari pihak yang disupervisi. 
9. Supervisi adalah sebuah kegiata yang hasilnya memerlukan proses yang kadang-kadang tidak sederhana. Oleh karena itu tidak pantas seorang supervisor mengharapkan hasil yang terlalu cepat.

10. Supervisi hendaknya bersifat preventif, korektif, kooperatif. Preventif berarti berusaha mencegah jangan sampai timbul hal yang negatif, dengancara mengantisipasi bakal terjadinya peristiwa yang tak diinginkan. Korektif berarti memperbaiki kesalahan- kesalahan yang telah diperbuat untuk memperoleh sesuatu yang tidak mengulangi kejadian yang lama. Kooperatif berarti berusaha melakukan dan mengatasi secara bersama-sama ketika terjadi hal- hal yang tidak dinginkan.

\section{Fungsi Supervisi Pendidikan}

Pidarta (2009) fungsi utama supervisi adalah membantu sekolah menciptakan lulusan yang baik dalam kualitas dan kuantitas, serta membantu para guru agar bisa dan dapat bekerja secara profesional sesuai dengan kondisi masyarakat tempat sekolah itu berada.

Fungsi supervisi menyangkut bidang kepemimpinan, hubungan kemanusiaan, pembinaan proses kelompok, administrasi personil, dan bidang evaluasi. Pengertian supervisi tersebut, mempertegas bahwa supervisi dilakukan secara intensif kepada guru. Hal ini, secara tidak langsung berdampak pada prestasi belajar siswa. Berpijak pada keterangan ini, maka supervisi pendidikan mempunyai tiga fungsi, yaitu:

1. Sebagai suatu kegiatan untuk meningkatkan mutu pendidikan

2. Sebagai pemicu atau penggerak terjadinya perubahan pada unsur-unsur yan terkait dengan pendidikan

3. Sebagai kegiatan dalam hal memimpin dan membimbing 
Dari sini, supervisi pendidikan bisa mencerahkan dan memperbaiki secara konsisten program lembaga pendidikan sehingga meraih kesuksesan.

Menurut Suharsimi Arikunto dalam Nadhirin, fungsi supervisi yaitu pertama, fungsi peningkatan mutu pembelajaran yang tertuju pada aspek akademik yang terjadi di ruang kelas ketika guru sedang memberikan bantuan, bimbingan dan arahan kepada siswa. Kedua, fungsi memicu unsur yaitu berfungsi sebagai alat penggerak terjadinya perubahan yang tertuju pada unsur-unsur yang terkait dengan atau bahkan faktor-faktor yang berpengaruh terhadap peningkatan kualitas pembelajaran. Ketiga, fungsi membina dan memimpin yaitu pelaksanaan supervisi pendidikan diarahkan kepada guru dan tenaga tata usaha.

Menurut Nadhirin, fungsi supervisi yaitu sebagai upaya yang dilakukan oleh supervisor dalam rangka membina para guru agar kualitas proses pembelajaran dan hasilnya meningkat, serta mengupayakan agar guru lebih meningkatkan kinerja sehingga dapat menyesuaikan dengan tuntutan profesi yang ada

\section{E. Objek Supervisi Pendidikan}

Dalam pelaksanaannya, kegiatan supervisi diarahkan pada pembinaan dan pengembangan aspek-aspek yang berkaitan dengan proses pembelajaran. Guru merupakan komponen yang terlibat langsung dan bertanggung jawab atas proses pembelajaran di kelas, sehingga yang menjadi fokus atau sasaran utama supervisi adalah yang berkaitan dengan guru.

Obyek supervisi pendidikan merupakan sasaran dari pelaksanaan supervisi, yaitu supervisi ditujukan kepada pembinaan personil dan non personil. Supervisi terhadap personil dimaksudkan sebagai upaya melakukan pengawasasn terhadap individu-individu yang terlibat dalam pelaksanaan proses pendidikan, antara lain kepala, guru mata pelajaran, guru kelas, staff usaha, dan tenaga 
kependidikan lainnya. Supervisi non-personil dimaksudkan sebagai upaya kepengawasan yang dilakukan supervisor terhadap berbagai kesiapan dan kelengkapan sarana dan prasarana sekolah dalam menunjang pelaksanaan proses pendidikan antara lain perpustakaan, administrasi sekolah, ketersediaan buku ajar, program perencanaan pendidikan dan sarana pendidikan lainnya. Obyek sasaran supervisi pendidikan secara lebih mendalam sebenarnya adalah sasaran berupa peningkatan kemampuan guru. Dengan demikian, dapat diambil kesimpulan bahwa yang menjadi sasaran atau obyek supervisi pendidikan adalah unsur-unsur yang berkaitan dengan proses pembelajaran. Guru merupakan faktor utama dalam proses pembelajaran dan gurulah yang mempunyai kewenangan untuk merancang bagaimana proses pembelajaran yang akan dilaksanakan.

Ditinjau dari obyek yang disupervisi, ada tiga macam supervisi, yaitu:

1. Supervisi akademik, yang menitikberatkan supervisor pada masalah-masalah akademik yaitu hal-hal yang langsung berada dalam lingkungan pembelajaran pada waktu siswa sedang dalam proses mempelajari sesuatu.

2. Supervisi administrasi, yang menitikberatkan pada pengamatan supervisor pada aspek-aspek administrasi yang berfungsi sebagai pendukung dan pelancar terlaksananya pembelajaran.

3. Supervisi lembaga, yang menyebarkan obyek pengamatan supervisor pada aspek-aspek yang berada di seantero sekolah.

4. Critical Thinking

Disisi lain, objek dari supervisi pendidikan terbagi menjadi dua bagian, yakni pembinaan personil dan pembinaan non personil.

1. Pembinaan Personil

a. Kepala Sekolah. 
b. Pendidik.

Pembinaan yang dilakukan oleh supervisor kepada guru bisa berupa pembinaan secara individu maupun secara kelompok. Adapun point-point yang menjadi supervisi guru antara lain adalah : 1)Kinerja Guru; 2) KBM Guru; 3) Karakteristik Guru; 4) Administrasi Guru dan lain-lain

c. Staff Sekolah

Staff Sekolah ataupun Tenaga Kependidikan Sekolah adalah sama. Pembinaan atau supervisi terhadap staff sekolah dilakukan oleh Kepala Sekolah sama seperti guru, namun dalam staff sekolah yang perlu disupervisi adalah tentang kinerja staff, penataan administrasi sekolah, kemampuan dalam dalam bekerja atau skill serta loyatitas terhadap pimpinan atau kepala sekolah.

d. Peserta Didik.

Peserta didik atau siswa merupakan bagian dari sistem pendidikan sekolah yang saling terkait satu sama lainnya. Dan siswa yang menjadi objek dari pelaksanaan kegiatan belajar mengajar tersebut, juga ikut disupervisi. Contoh: administrasi kesiswaan, kahadiran dan kedisiplinan siswa, pengembangan diri, organisasi siswa dan lain-lain.

\section{Pembinaan Non Personil}

Pembinaan Non Personil menitik beratkan pada pembinaan sarana dan prasarana yang mendukung jalannya proses Pendidikan.

Sarana pendidikan terdiri dari 3 kelompok besar yaitu

a. Bangunan dan perabot sekolah

b. Alat pelajaran yang terdiri dari pembukuan, alat-alat peraga dan laboratorium.

c. Media pendidikan

Dengan demikian, supervisi mempunyai fungsi penilaian (evaluation) dengan jalan penelitian (research) dan merupakan 
usaha perbaikan (improvement). Menurut Swearingen fungsi supervisi pendidikan adalah mengkoordinir semua usaha sekolah, memperlengkapi kepemimpinan sekolah, memperkuat pengalaman-pengalaman guna menstimulasi usaha-usaha yang kreatif, memberikan fasilitas dan penilaian terus menerus, menganalisa situasi belajar mengajar, memberikan pengetahuan kepada setiap anggota, mengintegrasikan tujuan pendidikan dan membantu meningkatkan kemampuan mengajar.

\section{LATIHAN SOAL}

\section{Kerjakan soal-soal dibawah ini!}

1. Apa yang saudara pahami tentang supervisi Pendidikan?

2. Sebutkan prinsip-prinsip supervisi dalam Pendidikan!

3. Jelaskan tujuan supervisi Pendidikan pada Lembaga!

4. Apa fungsi supervisi bagi Lembaga Pendidikan?

5. Sebutkan obyek dalam supervisi Pendidikan! 


\section{BAB V \\ Model, Pendekatan, dan Teknik Supervisi Pendidikan}

\section{A. Model Supervisi Pendidikan.}

Model berasal dari Bahasa Inggris Modle, yang bermakna bentuk atau kerangka sebuah konsep, atau pola. Khusus dalam bahasan ini adalah model yang berkaitan dengan supervisi, lebih tepat menggunakan istilah acuan yang dipakai dalam melaksanakan supervisi. Sahertian (2000) membagi model supervisi menjadi empat bentuk :

a). Model konvensional (tradisional)

Model ini tidak lain dari refleksi dari kondisi masyarakat pada suatu saat. Pada saat kekuasaan yang otoriter dan feodal, akan berpengaruh pada sikap pemimpin yang otokrat dan korektif. Pemimpin cenderung untuk mencari-cari kesalahan. Perilaku supervisi ialah mengadakan inspeksi untuk mencari kesalahan dan menemukan kesalahan. Kadang-kadang bersifat memata-matai. Perilaku seperti ini disebut snooper vision(memata-matai). Sering disebut supervisi yang korektif. Memang sangat mudah untuk mengoreksi kesalahan orang lain, tetapi lebih sulit lagi "untuk melihat segi-segi positif dalam hubungan dengan hal-hal yang baik “. Pekerjaan seorang supervisor yang bermaksud hanya untuk mencari kesalahan adalah suatu permulaan yang tidak berhasil. Mencari-cari kesalahan dalam membimbing sangat bertentangan dengan prinsip dan tujuan supervisi pendidikan. Akibatnya yang disupervisi merasa tidak puas dan ada dua sikap yang tampak dalam kinerja yang disupervisi : 1) Acuh tak acuh (masa bodoh), dan (2) Menantang (agresif).Praktek mencari- cari kesalahan dan menekan bawahan ini masih tampak sampai saat ini. Para pengawas datang ke sekolah dan menanyakan mana satuan pelajaran. Ini salah dan 
seharusnya begini. Praktek-praktek supervisi seperti ini adalah cara memberi supervisi yang konvensional. Ini bukan berarti bahwa tidak boleh menunjukkan kesalahan. Masalahnya ialah bagaimana cara kita mengkomunikasikan apa yang dimaksudkan sehingga yang disupervisi menyadari bahwa dia harus memperbaiki kesalahan. Yang disupervisi akan dengan senang hati melihat dan menerima bahwa ada yang harus diperbaiki. Caranya harus secara taktis pedagogis atau dengan perkataan lain, memakai bahasa penerimaan bukan bahasa penolakan.

b). Model Supervisi IImiah

Supervisi yang bersifat ilmiah memiliki ciri-ciri sebagai berikut:

(1) Dilaksanakan secara berencana dan kontinu, (2) Sistematis dan menggunakan prosedur serta teknik tertentu, (3) Menggunakan instrumen pengumpulan data, (4) Ada data yang objektif yang diperoleh dari keadaan yang riil. Dengan menggunakan merit rating, skala penilaian atau checklist lalu mahasiswa menilai proses kegiatan belajar-mengajar guru di kelas. Hasil penilaian diberikan kepada guru sebagai balikan terhadap penampilan mengajar guru pada semester yang lalu. Data ini berbicara kepada guru dan guru kemudian mengadakan perbaikan. Penggunaan alat perekam data ini berhubungan erat dengan penilaian. Walaupun demikian, hasil perekam data secara ilmiah belum merupakan jaminan untuk melaksanakan supervisi yang lebih manusiawi.

c). Model Supervisi Klinis

Supervisi klinis adalah bentuk supervisi yang difokuskan pada peningkatan mengajardengan melalui siklus yang sistematik, dalam perencanaan, pengamatan serta analisis yang intensif dan cermat tentang penampilan mengajar yang nyata, serta bertujuan mengadakan perubahan dengan cara yang rasional.Supervisi klinis adalah proses membantu guru memperkecil kesenjangan antara tingkah laku mengajar yang nyata dengan tingkah laku mengajar yang ideal. 


\section{d). Model Supervisi Artistik}

Mengajar adalah suatu pengetahuan (knowledge), mengajar itu suatu keterampilan (skill), tapi mengajar juga suatu kiat (art). Sejalan dengan tugas mengajar, supervisi juga merupakan kegiatan mendidik sehingga dapat dikatakan bahwa supervisi adalah suatu pengetahuan, suatu keterampilan dan juga suatu kiat. Supervisi itu menyangkut bekerja untuk orang lain (working for the others), bekerja dengan orang lain (working with the others), bekerja melalui orang lain (working through the others). Dalam hubungan bekerja dengan orang lain maka suatu rantai hubungan kemanusiaan adalah unsur utama. Hubungan antar manusia dapat tercipta bila ada kerelaan untuk menerima orang lain sebagaimana adanya. Hubungan itu dapat tercipta bila ada unsur kepercayaan. Saling percaya, saling mengerti, saling menghormati, saling mengakui, saling menerima seseorang sebagaimana adanya.

\section{B. Pendekatan Supervisi Pendidikan}

Pendekatan berasal dari kata approach adalah cara mendekatkan diri kepada objek atau langkah-langkah menuju objek. Sudjana (2004) membagi pendekatan supervisi menjadi dua, yaitu: pendekatan langsung (direct contact) dan pendekatan tidak langsung (indirect contact). Pendekatan pertama dapat disebut dengan pendekatan tatap muka dan kedua, pendekatan menggunakan perantara, seperti melalui surat menyurat, media massa, media elekronik, radio, kaset, internet dan yang sejenis. Sementara dikenal juga pendekatan kolaboratif, yaitu pendekatan yang menggabungkan kedua pendekatan itu. Pendekatan yang digunakan dalam menerapkan supervisi modern didasarkan pada prinsip- prinsip psikologis. Suatu pendekatan atau teknik 
pemberian supervisi, sebenarnya juga sangat bergantung kepada prototipe orang yang disupervisi.

Sahertian(2000) mengemukakan beberapa pendekatan, perilaku supervisor berikut :

a). Pendekatan langsung (direktif)

Pendekatan direktif adalah cara pendekatan terhadap masalah yang bersifat langsung. Supervisor memberikan arahan langsung, sudah tentu pengaruh perilaku supervisor lebih dominan. Pendekatan direktif ini berdasarkan pada pemahaman terhadap psikologis behaviouristis. Prinsip behaviourisme ialah bahwa segala perbuatan yang berasal dari refleks, yaitu respons terhadap rangsangan/ stimulus. Oleh karena guru memiliki kekurangan, maka perlu diberikan rangsangan agar ia bisa bereaksi lebih baik. Supervisor dapat menggunakan penguatan (reinforcement)atau hukuman (punishment). Pendekatan seperti ini dapat dilakukan dengan perilaku supervisor seperti berikut ini :

1) Menjelaskan, 2) Menyajikan, 3) Mengarahkan, 4) Memberi contoh, 5) Menerapkan tolok ukur, dan 6) Menguatkan.

\section{b). Pendekatan tidak langsung (Non-Direktif)}

Yang dimaksud dengan pendekatan tidak langsung (non-direktif) adalah cara pendekatan terhadap permasalahan yang sifatnya tidak langsung.Perilaku supervisor tidak secara langsung menunjukkan permasalahan,tapi ia terlebih dulu mendengarkan secara aktif apa yang dikemukakan oleh dosen. la memberi kesempatan sebanyak mungkin kepada yang disupervisi untuk mengemukakan permasalahan yang mereka alami. Pendekatan non-direktif ini berdasarkan pada pemahaman psikologis humanistik. Psikologi humanistik sangat menghargai orang yang akan dibantu. Oleh karena pribadi guru yang dibina begitu dihormati, maka ia lebih banyak mendengarkan permasalahan yang dihadapi oleh guru. Yang disupervisi mengemukakan masalahnya. Supervisor mencoba 
mendengarkan, dan memahami apa yang dialami. Perilaku Ketiga supervisor dalam pendekatan non-direktif adalah sebagai berikut : Mendengarkan, Memberi penguatan, Menjelaskan, Menyajikan, dan Memecahkan masalah.

\section{c). Pendekatan kolaboratif}

Pendekatan kolaboratif adalah cara pendekatan yang memadukan cara pendekatan direktif dan non-direktif menjadi suatu cara pendekatan baru. Pada pendekatan ini, baik supervisor maupun yang disupervisi bersama-sama bersepakat untuk menetapkan struktur proses dan kriteria dalam melaksanakan proses percakapan terhadap masalah yang dihadapi. Pendekatan ini didasarkan pada psikologi kognitif. Psikologi kognitif beranggapan bahwa belajar adalah perpaduan antara kegiatan individu dengan lingkungan yang pada gilirannya akan berpengaruh dalam pembentukan aktivitas individu. Dengan demikian, pendekatan dalam supervisi berhubungan pada dua arah yakni dari atas ke bawah dan dari bawah ke atas. Perilaku supervisor dalam pendekatan ini adalah sebagai berikut, yakni :

1) Menyajikan,

2) Menjelaskan,

3) Mendengarkan,

4) Memecahkan masalah,

5) Negosiasi.

Pendekatan itu dilakukan dengan melalui tahap-tahap kegiatan pemberian supervisi sebagai berikut, yakni : 1) Percakapan awal (pre-conference), 2) Observasi, 3) Analisis/interpretasi, 4) Percakapan akhir (past - conference), 5) Analisis akhir, 6) Diskusi. 


\section{Teknik Supervisi}

Teknik adalah suatu metode atau cara melakukan hal-hal tertentu.Suatu teknik yang baik adalah terampil dan cepat menurut ( Hariwung : 1989), seorang supervisor harus memilih teknik-teknik khusus yang serasi. Teknik sebagai suatu metode atau cara melakukan hal-hal tertentu. Suatu teknik yang baik adalah terampil dan cepat, teknik dipakai menyelesaikan tugas yang dikerjakan sesuai rencana, spesifikasi atau tujuan yang dikaitkan dengan teknik yang bersangkutan. Teknik supervisi adalah alat yang digunakan oleh supervisor untuk mencapai tujuan supervisi itu sendiri yang pada akhirnya dapat melakukan perbaikan pengajaran yang sesuai dengan situasi dan kondisi. Teknik supervisi dapat dibagi menjadi dua macam , (a) Teknik Individual dan (b) Teknik Kelompok. Teknik individual adalah teknik yang dilaksanakan oleh guru oleh dirinya sendiri, sedangkan teknik kelompok adalah teknik yang dilakukan oleh beberapa orang atau secara bersama- sama.

1. Teknik Individual

a). Teknik Kunjungan Kelas

Teknik ini , dengan observasi kelas sama-sama dilakukan di ruang kelas,tetapi tidak sama. Perbedaannya dapat kita lihat pada tujuan dari teknik ini dimana tujuannya adalah untuk (1) membantu guru yang belum berpengalaman, (2) membantu guru yang sudah mengetahui tentang kekeliruan yang dilakukannya, (3) membantu guru yang baru pindah, (4) membantu melaksanakan proyek pendidikan, (5) mengamati perilaku guru pengganti, (6) mendengarkan nara sumber mengajar, (7) mengamati tim pengajar, (8) mengamati cara mengajar bidang-bidang studi istimewa, serta (9) membantu menilai pemakaian media pendidikan baik yang baru atau pun yang canggih.

b). Teknik Observasi Kelas 
Teknik observasi kelas dilakukan pada saat guru mengajar. Supervisor mengobservasi kelas dengan tujuan untuk memperoleh data tentang segala sesuatu yang terjadi ketika proses belajar mengajar sedang berlangsung. Data ini sebagai dasar bagi supervisor untuk melakukan pembinaan terhadap guru yang sedang diobservasi. Tentang waktu supervisor mengobservasi kelas ada yang diberitahu dan ada juga yang tidak diberi tahu sebelumnya, tetapi setelah melalui ijin supaya tidak mengganggu proses belajar mengajar.

c). Percakapan Pribadi

Adalah dialog yang dilakukan oleh guru dan supervisornya, yang membahas tentang keluhan-keluhan atau kekurangan yang dikemukakan oleh dosen dalam bidang mengajar, di mana di sini supervisor dapat memberikan jalan keluarnya.

d). Intervisitasi (mengunjungi kampus lain/ studi banding )

Teknik ini dilakukan oleh sekolah-sekolah yang masih kurang maju dengan mengutus beberapa orang staf pengajar untuk mengunjungi sekolah sekolah yang ternama dan maju dalam pengelolaannya untuk mengetahui kiat-kiat yang telah diambil sampai sekolah tersebut dapat maju.

e). Penyeleksi berbagai sumber materi untuk belajar ( Bacaan Terarah )

Cara untuk mengikuti perkembangan pengajaran, ialah dengan berusaha mengikuti perkembangan itu melalui kepustakaan profesional, dengan mengadakan "profesional reading ". Ini digunakan untuk menambah pengetahuan dan meningkatkan situasi belajar mengajar yang lebih baik.

f). Menilai diri sendiri

Dosen yang disupervisi dan supervisor melihat kekurangan masingmasing yang mana ini dapat memberikan nilai tambah pada hubungan guru dan supervisor tersebut, yang akhirnya akan memberikan nilai positif bagi kegiatan belajar mengajar yang baik. 
Menilai diri sendiri merupakan tugas yang tidak mudah, karena suatu pengukuran terbalik, karena selama ini guru hanya menilai mahasiswanya. Ada beberapa cara atau alat yang dapat digunakan untuk menilai diri sendiri, antara lain membuat daftar pandangan atau pendapat yang disampaikan kepada mahasiswa untuk menilai pekerjaan atau suatu aktivitas guru di muka kelas. Yaitu dengan menyusun daftar pertanyaan yang tertutup maupun terbuka, tanpa perlu menyebutkan nama siswa.

g). Supervisi yang memakai pendapat para siswa.

Teknik ini adalah dengan menanyakan kepada mahasiswa tentang belajar mengajar dan materi yang telah diajarkan. Hal ini dimaksudkan untuk menilai bagaimana hasil mengajar untuk peningkatan kualitas dalam mengajar.

2. Teknik Kelompok

a). Pertemuan Orientasi Bagi Guru Baru (Orientation Meeting for NewTeacher)

Pertemuan itu ialah salah satu daripada pertemuan yang bertujuan khusus mengantar dosen untuk memasuki suasana kerja yang baru. Hal-hal yang disajikan dalam pertemuan orientasi ini meliputi :

1) Sistem kerja dari sekolah itu.

Biasanya dilaksanakan melalui percakapan bersama, yang dapat juga diselingi dengan pengenalan fisik dan saling diskusi bersama yang disebut juga a round table discussion.

2) Proses dan mekanisme administrasi dan organisasi sekolah.

3) Biasanya diiringi dengan tanya jawab dan penyajian seluruh kegiatan dan situasi sekolah.

4) Sering juga pertemuan orientasi ini diikuti dengan tindak lanjut dalam bentuk diskusi kelompok, lokakarya selama beberapa hari, sepanjang tahun.

5) Ada juga melalui perkunjungan ke tempat-tempat tertentu, misalnya pusat-pusat industri, atau obyek-obyek sumber belajar. 
6) Salah satu ciri yang sangat berkesan bagi pembinaan segi sosial dalam orientasi ini ialah makan bersama.

7) Juga tempat pertemuan turut juga mempengaruhi orientasi itu.

8) Aspek lain yang membantu terciptanya suasana kerja, ialah bahwa guru baru itu tidak merasa asing tetapi ia merasa diterima dalam kelompok baru tersebut. Pertemuan orientasi ini juga dapat digunakan untuk merencanakan program kerja sekolah yang berhubungan dengan pembinaan tenaga pengajar dalam proses belajar mengajar

b). Panitia Penyelenggara

Suatu kegiatan bersama biasanya perlu diorganisasi. Untuk mengorganisasi sesuatu tugas bersama, ditunjuk beberapa orang penanggung jawab pelaksana. Para pelaksana yang dibentuk untuk melaksanakan sesuatu tugas yang lazim disebut panitia penyelenggara. Panitia ini yang bertugas melaksanakan tugas-tugas yang diberikan sekolah kepadanya, dengan demikian mereka nantinya akan banyak memperoleh pengalaman-pengalaman kerja. Pengalaman dalam usaha mencapai tujuan, pengalaman dalam mengerti cara bekerja sama dengan orang lain, pengalaman yang berhubungan dengan tugas yang dibebankan kepadanya. Berdasarkan pengalaman- pengalaman tersebut guru dapat bertambah dan bertumbuh dalam profesi mengajarnya.

c). Rapat Guru (teacher meeting)

Rapat guru berbeda dengan pertemuan formal karena pada rapat ini semua guru wajib hadir. Dalam rapat ini biasanya dibicarakan mengenai masalah pengajaran dan permasalahan siswa. Tujuan utamanya adalah untuk memperbaiki kualitas personal dan merencanakan program sekolah dan juga memberikan kesempatan untuk berpikir kooperatif, merencanakan staf, mendorong guru untuk berbicara dan dapat mengenal sekolah secara keseluruhan.

d). Tukar menukar pengalaman (sharring experience) 
Teknik ini dilaksanakan secara informal dimana setiap guru menyampaikan pengalaman masing-masing dalam mengajar terhadap topik-topik yang sudah diarahkan. Karena forum ini sifatnya umum maka akan memberikan suatu pengalaman yang berharga bagi guru muda (yunior) untuk memperkuat jati diri sebagai staf pengajar. Kesimpulan yang diperoleh akan dijadikan pegangan bagi semua guru dalam mensiasati pekerjaan mereka di kelas.

e). Lokakarya (Workshop)

Lokakarya ini dengan cara mendatangkan para ahli-ahli pendidikan untuk mendiskusikan masalah-masalah pendidikan. Ketika itu dosen dapat mengambil kesimpulan dari apa yang dibicarakan. Teknik ini adalah usaha untuk mengembangkan kemampuan berfikir dan bekerja sama baik mengenai masalah-masalah teoritis maupun praktis dengan maksud untuk meningkatkan kualitas hidup secara umum dan kualitas profesional secara khusus. Workshop atau lokakarya merupakan salah satu metode yang dapat ditempuh pengawas dalam melakukan supervisi manajerial.

f). Panel Diskusi (Panel Discussion)

Teknik ini dilakukan dihadapan guru oleh para pakar dari bermacam sudut ilmu dan pengalaman terhadap suatu masalah yang telah ditetapkan. Mereka akan melihat suatu masalah itu sesuai dengan pandangan ilmu dan pengalaman masing-masing sehingga guru dapat memperoleh masukan yang sangat lengkap dalam menghadapi atau memecahkan suatu masalah. Manfaat dari kegiatan ini adalah munculnya sifat cekatan dalam memecahkan masalah dari berbagai sudut pandang ahli.

g ). Simposium

Kegiatan mendatangkan seorang ahli pendidikan untuk membahas masalah pendidikan. Simposium menyuguhkan pidato-pidato pendek yang meninjau suatu topik dari aspek-aspek yang berbeda.Penyuguh pidato biasanya tiga orang dimana guru sebagai 
pengikut diharapkan dapat memperoleh manfaat dengan mendengarkan pidato-pidato tersebut.

h). Demonstrasi mengajar

Usaha peningkatan belajar mengajar dengan cara mendemonstrasikan cara mengajar dihadapan guru dalam mengenalkan berbagai aspek dalam mengajar di kelas, oleh supervisor.

i). Buletin supervisi.

Suatu media yang bersifat cetak dimana disana didapati peristiwa peristiwa pendidikan yang berkaitan dengan cara cara mengajar, tingkahlaku siswa, dansebagainya. Diharapkan kebijakan ini dapat membantu guru untuk menjadi lebih baik.

j). Membaca langsung

Kegiatan ini dilakukan guru secara perseorangan, dimana guru membaca buku-buku pendidikan yang akan membantu guru tersebut dalam proses belajar mengajar, memperkaya dan mengembangkan materi perkuliahan, memperluas aplikasi sesuai teori, memperluas relevansi materi kuliah dengan berbagai teori lain.

n). Mengikuti kursus

Teknik ini dilakukan oleh guru untuk meningkatan pengetahuan dan keterampilan mereka dalam mengajar agar tidak monoton.

o) Supervisi Sebaya (Peer Supervising)

Sejajar dengan prinsip metodologi belajar mengajar bahwa anak yang pintar diperbolehkan membantu teman-temannya dalam belajar, walaupun ia tidak berhak dalam memberi penilaian keberhasilan guru yang dibantu mengajar. Teknik ini sangat berguna dalam share pengalaman guru dari teman seprofesi dalam bidangnya. Mereka akan saling mendapatkan kiat-kiat yang ada pada masing-masing teman terutama pada materi - materi sulit.

p) Supervisi dengan pemanfaatan IT

Teknik ini memanfaatkan IT sehingga guru tidak gaptek 
q) Pemanfaatan Nara Sumber

Sumber yang dapat memberikan pendalaman dan perluasan ilmu secara langsung, dengan kemungkinan untuk berinteraksi dan memberikan penjelasan secukupnya, berupa seorang ahli yang dapat didatangkan sebagai nara sumber (resource person ).

\section{LATIHAN SOAL}

\section{Kerjakan soal dibawah ini dengan benar}

Apa yang dimaksud dengan supervisi Pendidikandan siapa yang dimaksud dengan supervisor di sekolah?

Sebutkan model supervisi Pendidikan!

Apa saja pendekatan yang digunakan kepala sekolah dalam melakukan supervisi!

Bagaimana Teknik supervisi yang efektif dalam Pendidikan? Mengapa sekolah wajib melakukan supervisi? 


\section{BAB VI \\ Administrasi Pendidikan dalam SNP}

Administrasi sekolah adalah suatu proses keseluruhan kegiatan yang berupa merencanakan, mengatur (mengurus), melaksanakan dan mengendalikan semua urusan sekolah untuk mencapai tujuan pendidikan dan pengajaran di sekolah. Administrasi sekolah merupakan suatu proses pemanfaatan segala sumber (potensi) yang ada di sekolah baik personil (Kepala Sekolah dan stafnya serta guru-guru dan karyawan sekolah lainnya) maupun material (kurikulum, alat/media) dan fasilitas (sarana dan prasarana) serta dana yang ada di sekolah secara efektif. Penataan administrasi bagi sekolah menjadi begitu penting sebagai sumberdata utama manajemen sekolah dalam mengatur proses belajar mengajar dengan tertib sehingga tercapainya tujuan sekolah.

Secara lebih spesifik, administrasi sekolah berfungsi :

- Memberi arah dalam penyelenggaraan pendidikan di sekolah

- Memberikan umpan balik bagi perbaikan proses dan hasil pendidikan di sekolah

- Meningkatkan mutu penyelenggaraan administrasi sekolah

- Menunjang tercapainya tujuan/program sekolah secara efektif dan efisien

Saat ini penataan administrasi sekolah lebih mengacu pada 8 Standar Nasional Pendidikan. Akan tetapi yang sering timbul di lapangan, kita terkadang bingung mengenai jenis-jenis administrasi yang mengacu kepada 8 standar tersebut. Oleh karena itu berikut ini kami sajikan beberapa contoh jenis administrasi yang sesuai dengan 8 standar nasional pendidikan tersebut. Dalam hal ini sesungguhnya sekolah dapat menyiapkan administrasi dengan 8 SNP sesuai dengan instrument akreditasi yang dilakukan oleh 
Badan Akreditasi Provinsi Jawa Timur. Namun demikian didalam buku ini akan penulis sajikan secara global tentang administrasi 8 SNP

\section{A. Standar Isi}

Standar Isi mencakup lingkup materi minimal dan tingkat kompetensi minimal untuk mencapai kompetensi lulusan minimal pada jenjang dan jenis pendidikan tertentu. Standar isi memuat kerangka dasar dan struktur kurikulum, beban belajar, kurikulum tingkat satuan pendidikan, dan kalender pendidikan. Standar Isi Kesetaraan untuk pendidikan program paket.

Administrasi yang perlu disiapkan sebagai berikut :

a. KTSP/Kurikulum 2013

b. Kalender Pendidikan

c. Buku Pelajaran

d. Berita acara rapat dan daftar hadir (guru, komite dan tokoh masyarakat)

e. Referensi pengembangan kurikulum

f. SK tim pengembang kurikulum

g. Dokumen RPP

h. Program pengembangan diri (program layanan bimbingan konseling dan program ekstrakurikuler)

i. Dokumen tugas siswa (Tugas terstruktur dan tugas mandiri tidak terstruktur)

j. Silabus Pembelajaran

k. Berita acara pengembangan KTSP/kurikulum 2013

I. Berita acara penetapan KKM dan daftar hadir

\section{B. Standar Proses}

Proses pembelajaran pada satuan pendidikan diselenggarakan secara interaktif, inspiratif, menyenangkan, menantang, memotivasi peserta didik untuk berpartisipasi aktif, serta memberikan ruang yang cukup bagi prakarsa, kreativitas, dan 
kemandirian sesuai dengan bakat, minat, dan perkembangan fisik serta psikologis peserta didik. Selain itu, dalam proses pembelajaran pendidik memberikan keteladanan. Setiap satuan pendidikan melakukan perencanaan proses pembelajaran, pelaksanaan proses pembelajaran, penilaian hasil pembelajaran, dan pengawasan proses pembelajaran untuk terlaksananya proses pembelajaran yang efektif dan efisien.

Administrasi yang perlu disiapkan sebagai berikut :

a. RPP

b. Dokumen perencanaan, pemantauan, pelaksanaan pemantauan, dan laporan pemantauan proses pembelajaran disertai catatan kepala sekolah.madrasah dan tanda tangan guru yang dipantau

c. Catatan hasil evaluasi proses pembelajaran oelh kepala sekolah

d. Dokumen laporan pengawasan proses pembelajaran

e. Dokumen tindak lanjut hasil evaluasi

\section{Standar Kompetensi Lulusan}

Standar Kompetensi Lulusan (SKL) untuk satuan pendidikan dasar dan menengah digunakan sebagai pedoman penilaian dalam menentukan kelulusan peserta didik. Standar Kompetensi Lulusan meliputi standar kompetensi lulusan minimal satuan pendidikan dasar dan menengah, standar kompetensi lulusan minimal kelompok mata pelajaran, dan standar kompetensi lulusan minimal mata pelajaran. Standar Kompetensi Lulusan meliputi:
a. SKL Satuan Pendidikan \& Kelompok Mata Pelajaran
b. SKL Mata Pelajaran SD-MI
c. SKL Mata Pelajaran SMP-MTs
d. SKL Mata Pelajaran SMA-MA
e. SKL Mata Pelajaran PLB ABDE
f. SKL Mata Pelajaran SMK-MAK 
Administrasi yang perlu disiapkan sebagai berikut :
a. RPP
b. Tugas siswa
c. Tata Tertib Sekolah
d. Piagam penghargaan siswa
e. Dokumen Ujian Sekolah

\section{Standar Pendidik Dan Kependidikan}

Pendidik harus memiliki kualifikasi akademik dan kompetensi sebagai agen pembelajaran, sehat jasmani dan rohani, serta memiliki kemampuan untuk mewujudkan tujuan pendidikan nasional. Kualifikasi akademik yang dimaksudkan adalah tingkat pendidikan minimal yang harus dipenuhi oleh seorang pendidik yang dibuktikan dengan ijazah dan/atau sertifikat keahlian yang relevan sesuai ketentuan perundang-undangan yang berlaku. Kompetensi sebagai agen pembelajaran pada jenjang pendidikan dasar dan menengah serta pendidikan anak usia dini meliputi:

a. Kompetensi pedagogik;

b. Kompetensi kepribadian;

c. Kompetensi profesional; dan

d. Kompetensi sosial.

Pendidik meliputi pendidik pada TK/RA, SD/MI, SMP/MTs, SMA/MA, SDLB/SMPLB/SMALB, SMK/MAK, satuan pendidikan Paket $A$, Paket $B$ dan Paket $C$, dan pendidik pada lembaga kursus dan pelatihan. Tenaga Kependidikan meliputi kepala sekolah/madrasah, pengawas satuan pendidikan, tenaga administrasi, tenaga perpustakaan, tenaga laboratorium, teknisi, pengelola kelompok belajar, pamong belajar, dan tenaga kebersihan.

Administrasi yang perlu disiapkan sebagai berikut :

a. Ijazah dan Sertifikat 
b. Dokumen rapat guru (surat undangan, daftar hadir, notulen rapat)

c. Daftar hadir guru selama 1 semester (rekap kehadiran)

d. Sertifikat pendidik dan jadwal mengajar

e. Ijazah kepala sekolah dan sertifikat pendidik

f. Surat keterangan pengalaman mengajar kepala sekolah minimal 3-5 tahun

g. Dokumen pengelolaan selama 3 tahun terakhir (dokumen jumlah siswa, prestasi siswa, pengembanagan profesi guru, pengembangan kurikulum, perkembangan sarana dan prasarana, kerjasama dengan pihak terkait)

h. Pembukuan pengeloaan keuangan bidang kewirausahaan

i. Dokumen surat perjanjian, piagam atau dokumen lain.

j. Dokumen supervisi

k. Ijazah tenaga administrasi

I. Ijazah tenaga perpustakaan

m. SK Kepala sekolah (penjaga, tenaga kebersihan, pesuruh, dII)

\section{E. Standar Sarana Dan Prasarana}

Setiap satuan pendidikan wajib memiliki sarana yang meliputi perabot, peralatan pendidikan, media pendidikan, buku dan sumber belajar lainnya, bahan habis pakai, serta perlengkapan lain yang diperlukan untuk menunjang proses pembelajaran yang teratur dan berkelanjutan. Setiap satuan pendidikan wajib memiliki prasarana yang meliputi lahan, ruang kelas, ruang pimpinan satuan pendidikan, ruang pendidik, ruang tata usaha, ruang perpustakaan, ruang laboratorium, ruang bengkel kerja, ruang unit produksi, ruang kantin, instalasi daya dan jasa, tempat berolahraga, tempat beribadah, tempat bermain, tempat berkreasi, dan ruang/tempat lain yang diperlukan untuk menunjang proses pembelajaran yang teratur dan berkelanjutan. 
Administrasi yang perlu disiapkan sebagai berikut :

1. Surat izin mendirikan bangunan

2. Surat ijin penggunaan bangunan

3. Laporan pemeliharaan bangunan

4. Buku teks pelajaran

\section{F. Standar Pengelolaan}

Standar Pengelolaan terdiri atas:

a. Standar pengelolaan oleh satuan pendidikan.

b. Standar pengelolaan oleh Pemerintah Daerah.

c. Standar pengelolaan oleh Pemerintah

Administrasi yang perlu disiapkan sebagai berikut :

a. Dokumen visi, misi dan tujuan sekolah

b. RKS dan RKAS

c. KTSP, Kalender pendidikan, struktur organisasi, pendayagunaan pendidik dan tenaga kependidikan, peraturan sekolah, tata tertib, kode etik, biaya operasi sekolah, program pembelajaran, penilaian hasil belajar siswa

d. Dokumen layanan konseling, pembinaan prestasi, ekstrakurikuler, daftar alumni

e. Program pendayagunaan pendidik (pembagian tugas, penentuan sistem penghargaan, pengembangan profesi, promosi dan penempatan, mutasi)

f. Program pengelolaan sarana dan prasarana (perencanaan, pemenuhan, pendayagunaan, evaluasi, pemeliharaan dan sarana prasarana pembelajaran)

g. Dokumen pelaksanaan kegiatan sekolah (tata tertib, kode etik)

h. Program pengawasan dan bukti sosialisasi program

i. Laporan evaluasi diri sekolah

j. Laporan evaluasikinerja pendidik dan tenaga kependidikan

k. Dokumen akreditasi, tim pelaksana persiapan, bukti fisik non dokumen

I. Agenda kerja kepala sekolah, 
m. Software sistem informasi manajemen

\section{G. Standar Pembiayaan}

Pembiayaan pendidikan terdiri atas:

a. Biaya investasi satuan pendidikan meliputi biaya penyediaan sarana dan prasarana, pengembangan sumberdaya manusia, dan modal kerja tetap.

b. Biaya personal sebagaimana dimaksud pada di atas meliputi biaya pendidikan yang harus dikeluarkan oleh peserta didik untuk bisa mengikuti proses pembelajaran secara teratur dan berkelanjutan.

c. Biaya operasi satuan pendidikan meliputi: Gaji pendidik dan tenaga kependidikan serta segala tunjangan yang melekat pada gaji, Bahan atau peralatan pendidikan habis pakai, dan Biaya operasi pendidikan tak langsung berupa daya, air, jasa telekomunikasi, pemeliharaan sarana dan prasarana, uang lembur, transportasi, konsumsi, pajak, asuransi, dan lain sebagainya.

Administrasi yang perlu disiapkan sebagai berikut :

a. Dokumen investasi sarana dan prasarana

b. Dokumen pembelanjaan pengembangan pendidik dan tenaga kependidikan dan daftar peneriman tahun sebelumnya

c. RKAS

d. Daftar gaji

e. Laporan Keuangan

f. Pedoman pengelolaan keuangan

g. Laporan Dana BOS dan Blockgrant 


\section{H. Standar Penilaian}

Penilaian pendidikan pada jenjang pendidikan dasar terdiri atas: Penilaian hasil belajar oleh pendidik, Penilaian hasil belajar oleh satuan pendidikan, dan Penilaian hasil belajar oleh Pemerintah. Penilaian pendidikan pada jenjang pendidikan tinggi terdiri atas: Penilaian hasil belajar oleh pendidik, dan Penilaian hasil belajar oleh satuan pendidikan tinggi. Penilaian pendidikan pada jenjang pendidikan tinggi diatur oleh masing-masing perguruan tinggi sesuai peraturan perundang-undangan yang berlaku.

Administrasi yang perlu disiapkan sebagai berikut :

a. Silabus pembelajaran

b. RPP

c. Arsip tes, nilai tes, nilai pengamatan, dan nilai tugas terstruktur maupun mandiri.

d. Analisa hasil belajar

e. Buku penghubung guru dan orang tua dan bukti kerja siswa

f. Program remedial dan pengayaan serta revisi perangkat pembelajaran

g. Arsip hasil evaluasi belajar yang telah ditandatangani guru dan kepala sekolah/madrasah

h. Catatan hasil mengkomunikasikan penilaian dari guru ke guru yang bersangkutan

i. Program Ujian

j. Dokumen rapat, (surat undangan, berita acara rapat, hasil rapat, surat keputusan kepala sekolah/madrasah tentang kepanitian UTS, UAS dan Ujian Akir sekolah, serta rapat kenaikan kelas

k. Buku laporan

I. Laporan pencapaian hasil belajar

m. Dokumen ujian, ijazah

n. Berita acara penerimaan murid baru 
Berdasarkan pengalaman walaupun administrasi untuk akreditasi di atas sangat banyak tapi apabila dibiasakan untuk dibuat dan dikerjakan tidak akan terasa terbebani saat akan menghadapi proses akreditasi. Karena administrasi tersebut merupakan administrasi kegiatan sehari-hari, bulanan maupun tahunan. Oleh karena itu sekolah harus mulai membiasakan tertib administrasi. Bagi yang belum mempunyai perangkat atau instrumen akreditasi file dapat di unduh di internet atau web BAP tentang perangkat akreditasi sekolah secara lengkap.

\section{LATIHAN SOAL}

Kerjakan Soal dibawah ini

Jelaskan yang dimaksud dengan

1. Standar Isi

2. Standar Proses

3. Standar Kompetensi Lulusan

4. Standar Pendidik dan Kependidikan

5. Standar Sarana dan Prasarana

6. Standar Pengelolaan

7. Standar Pembiayaan

8. Standar Penilaian 


\section{DAFTAR PUSTAKA}

Afriyenti (2013). Pemberdayaan Pegawai Tata Usaha Dalam Rangka Meningkatkan Layanan Administratif. Jurnal Bahana Manajemen Pendidikan, Vo 1 (1), 9 -13.

Arikunto S, (2006). Prosedur Penelitian Suatu Pendekatan Praktik, Ed Revisi VI. Jakarta: PT Rineka Cipta

Arum, Wahyu Sri Ambar. (2007). Manajemen Sarana dan Prasarana. Jakarta:CV. Multi Karya Multi.

Brown, Rainer Rohdewohld (2005). Measuring Capacity Building. Carolina Population Centre/University of North Carolina: Chapel Hill

Castetter, W. B. (1996). $6^{\text {th }}$ ed. The Human Resource Function in Educational Administration. New Jersey: Prentice-Hall, Inc.

David, F. R. (2006). Manajemen Strategik: Konsep. Terj. Ichsan Setiyo Budi. Jakarta: Salemba Empat.

Davis, Ralph. (1951). The Fundamentals of Top Management. New York, Harper \& Brothers Publishers.

Drucker, P. F. (1996). Leader of The Future. New York: Jossey-Bass Inc. Dunn, W. N. (2003). Pengantar Analisis Kebijakan Publik. cet. 5. Yogyakarta: Gadjah Mada University Press.

Fattah, Nanang (2004). Landasan Manajemen Pendidikan. Bandung: Rosda Karya. Universitas Terbuka.

Greenlee B.J. (2010). Building Teacher Leadership Capacity through Educational Leadership Program. Journal of Reasearch for Educational Leaders JREL, 4 ( 1), hlm. 44 - 74 
Hartono, Didi. 2014. Pengaruh Sarana Prasarana Dan Lingkungan Kerja Terhadap Kinerja Pegawai Dinas Pendidikan Kota Banjarbaru, Kindai. 10 (2), 142-155.

Hazel Callaghan. (2011). Raising Standards Improving Lives : The Office for Standards in Education: Journal Ofsted Raising Standards Improving Lives, 3(2), hlm 10-12.

Handayaningrat, Soewarno. (1996). Pengantar Studi IImu Administrasi dan Manajemen. Jakarta. Gunung Agung.

Iswanto, Y. (2004). Manajemen Sumber Daya Manusia. Jakarta: Pusat Penerbitan Universitas Terbuka.

James P. Spillane \& Allison W. Kenney. (2012). School administration in a changing education sector the US experience: Journal of Educational Administration, 50(5), hlm. 541-561.

Kaplan, R. S. dan Norton D. P. (2000). Balance Scorecard: Menerapkan Strategi Menjadi Aksi. terj. Peter R. Yosi Pasla. Jakarta: Erlangga.

Lasswell, Harold D. (1971). A Preview of Policy. New York: American Elsevier Publishing Co.

Lubis, S. B. H. (2008). Pengantar Teori Organisasi. Bandung: PPS Uninus Bandung.

Manullang, B. (2006). Kepemimpinan Pedagogis. Medan: Program Pascasarjana Unimed.

Mulyasa, E. (2002). Manajemen Berbasis Sekolah: Konsep, Strategi, dan Implementasinya. Bandung: Rosda Karya. 
Mulyasa, E. (2007). Menjadi Kepala Sekolah Yang Profesional. Bandung: Remaja Rosdakarya.

Murdoch, Robert G. dan Ross, Joel E. (1990). Sistem Informasi Untuk Manajemen. Jakarta: Penerbit Erlangga.

Matseliso, L.M \& Loyiso C.J. (2008). Self Capacity Building for Teaching and Learning in Environmental Education - The Role of Public/Private Partnerships in the Mpumalanga Privince of South Africa. Journal International Cooperation in Education, 1 (3), hlm.. $39-54$

Morgan, Peter. (2008). The Concept Of Capacity. England: European Centre For Development Policy Management.

Nasution, S. (2005). Teknologi Pendidikan. Jakarta: Bumi Aksara.

Peraturan Menteri Pendidikan Nasional Republik Indonesia Nomor 24 Tahun 2008 tentang Standar Tenaga Administrasi Sekolah

Peraturan Pemerintah Republik Indonesia Nomor 32 Tahun 2013

Tentang Perubahan Atas Peraturan Pemerintah Nomor 19 Tahun 2005 Tentang Standar Nasional Pendidikan

Reynolds, L. J. (2005). Kiat Sukses Manajemen Berbasis Sekolah. cet. 2, terj. Teguh Budiharso dan Abdul Munir. Jakarta: CV. Diva Pustaka.

Rev. John Karihe, Prof. Namusonge, DR. Mike Iravo. (2015). Work Facilities as a Determinant of Occupational Stress and Employee Performance. International Journal of Science and Research, 4(5), hlm. $1925-1930$

Robbins, Stephen P. dan Coulter, Mary. (1999). Manajemen. Jakarta: PT. Prehallindo. 
Sagala, Syaiful. (2004). Manajemen Berbasis Sekolah \& Masyarakat., Jakarta: Nimas Multima.

Sagala, Syaiful. (2005). Administrasi Pendidikan Kontemporer. Bandung: CV. Alfabeta.

Thaib, M. A. dan Subagio, A. (2005). Cet. 1. Kepengawasan Kependidikan. Jakarta: Departemen Agama RI Direktorat Madrasah dan Pendidikan Agama Islam.

The Peter F. Drucker Foundation. (1996). The Leader of Future: new visions, strategies, and practises for the next era. San Francisco: Jossey-Bass Inc.

Wexley, K. N. dan Gary A. Yuki. (1988). Perilaku Organisasi dan Psikologi Personalia, terj. Muh. Shobaruddin. Jakarta: Bina Aksara.

Wibowo. (2007). Manajemen Kinerja. Jakarta: PT Rajagrafinda Persada.

Williams, Walter. (1971). The Experience in the Federal Social Agencies. New York: American Elsevier Publishing Co.

Zamroni. (2003). Pendidikan Untuk Demokrasi. Yogyakarta: Penerbit Bigraf 


\section{Biodata Penulis}

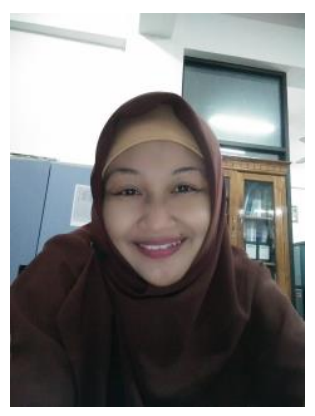

Ida Rindaningsih berprofesi sebagai dosen di Prodi Pendidikan Guru Ibtidaiyah Fakultas Agama Islam Universitas Muhammadiyah Sidoarjo. Lahir di Surabaya tahun 1977. Mengawali karir sebagi guru sejak tahun1995 dan menjadi dosen tahun 2002. Telah lulus S2 jurusan Manajemen Pendidikan pada tahun 2010. Dan sedang menempuh S3 di Universitas Negeri Malang. Konsen pada administrasi Pendidikan serta desain pembelajaran. Telah mengembangkan model pembelajaran berbasis Zona, model pembelajaran berbasis Arena, mengembangkan manajemen strategi PAUD berbasis BCCT, dan juga model pembelajaran flipped classroom di mata kuliah microteaching. 


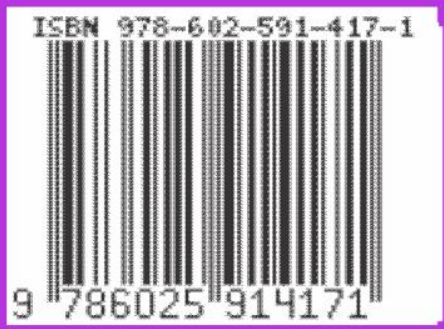

